http://dx.doi.org/10.18778/1509-877X.01.05

Artykuły

Filip Majdowski*

\title{
Regulacje CFC w ŚWietle pozostaŁyCH REKOMENDACJI OECD Z PROJEKTU BEPS - STOSUNEK ZBIEŻNOŚCI, WYKLUCZENIA ORAZ PARALELIZMU
}

\begin{abstract}
Streszczenie. Przedmiotem artykułu jest omówienie rekomendacji OECD wydanych na tle projektu Base Erosion and Profit Shifting (BEPS) odnośnie do relacji regulacji CFC z innymi działaniami w ramach tego projektu. Analiza wytycznych przedstawionych przez OECD do projektu BEPS pokazuje, iż nie mają one charakteru holistycznego, czyli nie przewidują one wyraźnej hierarchizacji tych wytycznych, oraz że oddziaływanie regulacji CFC na zjawisko BEPS ma większości przypadków charakter subsydiarny względem tych innych podstawowych rekomendacji, jak przykładowo wskazówek dotyczących neutralizacji hybrydyzacji podatkowej, ograniczenia potrącalności podatkowej płatności finansowych czy też zwalczania szkodliwych reżimów podatkowych.
\end{abstract}

Słowa kluczowe: BEPS, regulacje CFC, gospodarka cyfrowa, hybrydowe podmioty oraz płatności, szkodliwe reżimy podatkowe, ceny transferowe

\section{WPROWADZENIE}

Celem niniejszego opracowania jest przedstawienie i ocena rekomendacji OECD w zakresie regulacji kontrolowanej spółki zagranicznej (ang. controlled foreign company - CFC) na tle pozostałych punktów Planu

* Ukończył studia doktoranckie na Wydziale Prawa i Administracji Uniwersytetu Warszawskiego, wicedyrektor w Departamencie Systemu Podatkowego w Ministerstwie Finansów; artykuł wyraża poglądy autora i nie należy ich utożsamiać ze stanowiskiem instytucji której jest pracownikiem. 
Działań OECD z 2013 r., leżącego u podstaw projektu OECD przeciwko erozji podstawy opodatkowania oraz zapobieżenia przerzucaniu zysków (ang. Base Erosion and Profit Shifting - BEPS). Prace w ramach projektu BEPS toczyły się na forum OECD przez ponad dwa lata (2013-2015) $\mathrm{w}$ podziale na 15 strumieni tematycznych, gdzie jednym z poruszonych obszarów były wytyczne w zakresie wzmocnienia regulacji CFC. Wypada stwierdzić, iż zwalczanie zjawiska BEPS, a przynajmniej jego wybranych aspektów, może być przedmiotem równoczesnego oddziaływania więcej niż jednej kategorii rekomendacji z grupy wspomnianych 15 obszarów, czyli w zakresie interesującym dla niniejszego opracowania może dochodzić do korelacji regulacji CFC oraz innych instrumentów prawno-podatkowych opisywanych przez OECD. Z zamiarem weryfikacji czy taka interakcja ma charakter zamierzony oraz wewnętrznie spójny omówione zostaną wybrane raporty BEPS-owskie odpowiadające poszczególnym punktom z Planu Działań OECD z 2013 r. odczytywane w kontekście regulacji CFC, czemu towarzyszyć będzie założenie, iż czytelnik posiada podstawową wiedzę na temat tych raportów. Analizę tytułowego zagadnienia autor rozpocznie od zdefiniowania czym są regulacje CFC oraz na czym polega zjawisko BEPS, zarysuje następnie kontekst prac prowadzonych przez OECD w zakresie ograniczenia przedmiotowego zjawiska, by finalnie przejść do omówienia właściwych raportów BEPS-owskich oraz przedstawić wnioski końcowe.

\section{ISTOTA REGULACJI CFC}

Regulacje CFC to instrument prawno-podatkowy stosowany powszechnie przez rozwinięte i rozwijające się państwa jako remedium mające na celu zapobieżenie unikaniu opodatkowania poprzez wykorzystanie zagranicznych spółek położonych w państwach o niskim poziomie opodatkowania, przede wszystkim w rajach podatkowych oraz innych państwach oferujących preferencyjne reżimy podatkowe ${ }^{1}$. Regulacje CFC nakazują po spełnieniu zobiektywizowanych materialnie przesłanek, między innymi co do charakteru zagranicznej spółki, kontroli względem niej sprawowanej przez podatnika, oraz kategorii dochodów przez tę spółkę uzyskiwanych,

${ }^{1}$ R. Vann, International Aspects of Income Tax, [w:] V. Thuronyi (red.), Tax Law Design and Drafting, Hague 1998, s. 79; W. Haslehner, The Controlled Foreign Company Regime, [w:] D. Weber, J. van de Streek (red.), The EU Common Consolidated Corporate Tax Base: Critical Analysis, Alphen aan den Rijn 2017, s. 164. 
z uwzględnieniem poziomu ich opodatkowania, przypisać przypadającą na takiego podatnika część przedmiotowego dochodu i opodatkować go „W jego rękach”, pomimo braku jego rzeczywistego otrzymania, przykładowo $\mathrm{w}$ formie dywidendy ${ }^{2}$. Innymi słowy, regulacje CFC zatrzymują podatek w państwie stosującym te przepisy, który jest obliczany od dochodu z transakcji które zostały niejako „zablokowane” w zagranicznej spółce albo, inaczej rzecz ujmując, że komentowane przepisy neutralizują sztuczną alokację źródeł przychodów do zagranicznej spółki ${ }^{3}$.

\section{DefinicJa ZJAWISKA BEPS}

Jak podaje OECD, terminem BEPS definiuje się strategie planowania podatkowego, które mają na celu wykorzystywanie luk w przepisach podatkowych poszczególnych państw w celu ukrycia zysków, czyli sprawienia by stały się one niewidoczne, lub przeniesienia zysków do lokalizacji (jurysdykcji), gdzie jest prowadzona niewielka bądź żadna działalność gospodarcza, ale gdzie przedmiotowe zyski są nisko opodatkowane, co finalnie skutkuje uiszczeniem żadnego bądź niewysokiego podatku dochodowego ${ }^{4}$. W doktrynie zwrócono uwagę, iż termin BEPS zawiera równocześnie opis zjawiska w postaci przemieszczania dochodu oraz jego skutku w postaci obniżenia wpływów budżetowych państw doświadczających tego zjawiska ${ }^{5}$.

Z powyższej definicji wynika, iż zjawisko BEPS jest nakierowane na specyficznie rozumiane unikanie opodatkowania, które w kontekście międzynarodowym ma się przejawiać w podwójnym nieopodatkowaniu, bądź zbyt niskim opodatkowaniu, na skutek sztucznego oddzielenia dochodu od działalności go generującej ${ }^{6}$. W efekcie kluczowym celem projektu

${ }^{2}$ F. Majdowski, Polskie regulacje dotyczące zagranicznej spółki kontrolowanej na tle rekomendacji OECD oraz wymogów unijnych (cz. 1), „Biuletyn Instytutu Studiów Podatkowych" 2016, nr 9, s. 70 i n.

${ }^{3}$ K. Holmes, Regulacje zapobiegajace unikaniu opodatkowania, tłum. A. Biegalski, [w:] H. Hamaekers, K. Holmes, J. Głuchowski, T. Kardach, W. Nykiel, Wprowadzenie do międzynarodowego prawa podatkowego, Warszawa 2006, s. 286.

${ }^{4}$ OECD, BEPS Frequently Asked Questions, 2013, http://www.oecd.org/ctp/BEPSFAQsEnglish.pdf [dostęp: 7.04.2018].

${ }^{5}$ P. Piantavigna, Tax Abuse and Aggressive Tax Planning in the BEPS Era: How EU Law and the OECD Are Establishing a Unifying Conceptual Framework in International Tax Law, Despite Linguistic Discrepancies, „World Tax Journal” 2017, nr 1, s. 4.

${ }^{6}$ OECD/G-20, Tax Annex to the St. Petersburg G20 Leaders' Declaration, 2013, pkt 5. 
BEPS jest zapewnienie wystarczającego poziomu opodatkowania transgranicznego dochodu, czy to w państwie źródła, czy też w państwie rezydencji ${ }^{7}$. Część przedstawicieli nauki konkludowało na podstawie powyższego, że założeniem projektu BEPS jest realizacja zasady (wystarczającego) jednokrotnego opodatkowania dochodu w relacjach transgranicznych (ang. single tax principle) ${ }^{8}$ celem zapewnienia uczciwości oraz wewnętrznej spójności systemów podatkowych poszczególnych państw9. Tak zarysowany kontekst projektu BEPS pozwala zniuansować zjawisko BEPS od „klasycznie” pojmowanego zjawiska unikania opodatkowania, które było oceniane wyłącznie $\mathrm{z}$ perspektywy prawa wewnętrznego danego państwa. Podstawowym aspektem różnicującym te dwie sytuacje jest zasadniczo uniezależnienie w ramach BEPS zasady nakazującej opodatkowanie od niepodatkowych motywów działania podatnika, czyli ekonomicznego (gospodarczego) uzasadnienia danej transakcji. Nawet w sytuacji istnienia takich motywów nadrzędnym celem powinna być realizacja zasady jednokrotności, w domyśle - aczkolwiek niezdefiniowanego explicite - wystarczającego opodatkowania ${ }^{10}$. Można więc uznać, iż zajście zjawiska BEPS jest oderwane od sztuczności działania podatnika, co z kolei stanowiło konstytutywny element unikania opodatkowania rozumianego w dotychczasowy sposób. W piśmiennictwie prezentuje się również pogląd, iż zjawisko BEPS jest pojęciem szerszym (pojęciem zbiorczym), które obok „klasycznie” interpretowanego unikania opodatkowania polegającego na sztucznym odseparowaniu dochodu od działalności go kreującej wyróżnia przypadek wykorzystywania przez podatników różnic pomiędzy systemami podatkowymi poszczególnych państw, co do tej pory było raczej kwalifikowane jako dopuszczalne planowanie podatkowe (ang. tax planning) ${ }^{11}$.

${ }^{7}$ F. Vanistendael, Is Tax Avoidance the Same Thing under the OECD Base Erosion and Profit Shifting Action Plan, National Tax Law And EU Law?, „Bulletin for International Taxation" 2016, nr 3, s. 170.

${ }^{8} \mathrm{~A}$. Dourado, The Role of CFC Rules in the BEPS Initiative and in the EU, „British Tax Review" 2015, nr 3, s. 353.

${ }^{9}$ OECD/G-20, Tax Annex to the St. Petersburg G20 Leaders' Declaration 2013, pkt 5.

${ }^{10}$ P. Pistone, R. Szudoczky, The Coordination of tax Policies in the EU, [w:] M. Lang, P. Pistone, J. Schuch, C. Staringer (red.), Introduction to European Tax Law on Direct Taxation, Wien 2016, s. 46; F. Vanistendael, EU vs BEPS: Conflicting Concepts of Tax Avoidance, [w:] D. Weber (red.), EU Law and the Building of Gglobal Supranational Tax Law: EU BEPS and State Aid, Amsterdam 2017, książka online, s. 11.

${ }^{11}$ A. Dourado, The Meaning of Aggressive Tax Planning and Avoidance in the European Union and the OECD: an Example of Legal Pluralism in International Tax Law, 
W tym ostatnim przypadku w zachowaniu BEPS niekoniecznie musi wystąpić element unikania opodatkowania.

Termin BEPS zaczął funkcjonować w międzynarodowej debacie publicznej co najmniej od 2008 r. w kontekście agresywnego unikania opodatkowania $^{12}$ i sposobów przeciwdziałania nieuczciwemu zaniżaniu danin publicznych ${ }^{13}$, aczkolwiek niektórzy komentatorzy wiązaliby BEPS z praktykami podatników (korporacji) publicznie krytykowanymi już od pamiętnego stanowiska amerykańskiego prezydenta Kennedy’ego, który w 1961 r. zwracał uwagę na potrzebę ukrócenia tego typu praktyk w kontekście wprowadzenia amerykańskich regulacji CFC (ang. Subpart F) ${ }^{14}$. Coraz mniejsze wpływy budżetowe z podatków osiągane przez poszczególne państwa stały się na tyle istotne, że problem zapobiegania takim praktykom był dyskutowany na takich forach jak G-8, G-20, Unia Europejska, czy też w ramach poszczególnych państw.

\section{DziaŁania OECD pRzeciw BEPS}

Na spotkaniu G-20 w Los Cabos w Meksyku w dniach 18-19 czerwca 2012 r. przywódcy państw podjęli uchwałę o walce ze zjawiskiem erozji podstawy opodatkowania oraz transferu zysku ${ }^{15}$. Parę miesięcy później w mieście Meksyk, w dniach 4-5 listopada 2012 r., ministrowie finansów oraz szefowie banków centralnych państw G-20 wezwali OECD do opracowania raportu na temat tego zjawiska ${ }^{16}$.

[w:] J. English (red.), International Tax Law: New Challenges to and from Constitutional and Legal Pluralism, Amsterdam 2016, książka online, s. 6; P. Piantavigna, Tax Abuse and Aggressive Tax Planning in the BEPS Era: How EU Law and the OECD Are Establishing a Unifying Conceptual Framework in International Tax Law, Despite Linguistic Discrepancies, „World Tax Journal” 2017, nr 1, s. 13.

$12 \mathrm{Na}$ temat terminu „agresywnego unikania opodatkowania” zob. F. Majdowski, Zróżnicowane kryteria zwalczania zjawiska unikania opodatkowania w podatku dochodowym od osób prawnych, „Zeszyty Naukowe Sądownictwa Administracyjnego” 2016, nr 4, s. 74 i n.

${ }^{13}$ S. van Weeghel, F. Emmerink, Global Developments and Trends in International Anti-avoidance, „Bulletin for International Taxation” 2013, nr 8, s. 433.

${ }^{14}$ F. Majdowski, K. Bronżewska, Revolutionary Changes to the Arm's Length Principle under the OECD BEPS Project: Have CFC Rules Become Redundant?, „Intertax” 2018, nr 3, s. 214.

${ }^{15}$ G20, Communiqué from G20 leaders meeting (Los Cabos, Mexico), 2012, pkt 48.

${ }^{16}$ G20, Final Communiqué Meeting of Finance Ministers and Central Bank Governors, 2012, pkt 21 . 
4.1. Raport OECD na temat BEPS

Raport OECD na temat BEPS został opublikowany 12 lutego 2013 r. ${ }^{17}$ Jest to dokument przedstawiający zarys zjawiska BEPS oraz wyniki badań dotyczących jego skali od strony ekonomicznej, a także zawierający przegląd światowych trendów, które mają wpływ na kwestie opodatkowania międzynarodowych przedsiębiorstw. Raport OECD na temat BEPS skupia się na kluczowych zasadach, które leżą u podstaw opodatkowania transgranicznej działalności oraz wskazuje na okazje do BEPS, które są rezultatem tych zasad. Raport ten wzywa do współpracy na poziomie międzynarodowym w celu odpowiedzenia na efekty BEPS, podkreślając jednocześnie, iż jednostronne działania mogą skutkować pogłębieniem odmiennych klasyfikacji (hybrydyzacją) pomiędzy poszczególnymi państwami, dodatkowymi sporami, zwiększeniem niepewności obrotu oraz dalszym „wyścigiem w dół” w zakresie wysokości obciążeń podatkiem dochodowym. Jako jeden z kluczowych obszarów współpracy wskazanych w Raporcie OECD na temat BEPS wskazano obszar zapewnienia zwiększonej skuteczności instrumentów anty-abuzywnych, w tym regulacji $\mathrm{CFC}^{18}$.

\subsection{Plan Działań OECD}

W dniu 19 lipca 2013 r. opublikowano Plan Działań OECD ${ }^{19}$ z listą piętnastu krytycznych zadań, które OECD zobowiązało się podjąć. Fundamentalne zmiany do międzynarodowego systemu podatkowego, w tym koncepcji podziału na państwo rezydencji oraz państwo źródła zostały niemniej wykluczone ${ }^{20}$. Zadania określone przez OECD można określić jako mające na celu uszczelnienie międzynarodowego systemu podatkowego, które można skategoryzować w kilku podgrupach, jak ${ }^{21}$ :

a) prace dotyczące opodatkowania gospodarki cyfrowej (punkt 1 - gospodarka cyfrowa);

${ }^{17}$ OECD, Addressing Base Erosion and Profit Shifting, 2013, dalej: Raport OECD na temat BEPS.

${ }^{18}$ Raport OECD na temat BEPS, s. 48.

${ }^{19}$ OECD, Action Plan on Base Erosion and Profit Shifting, 2013.

${ }^{20} \mathrm{Ch}$. Panayi, International Tax law Following the OECD/G20 Base Erosion and Profit Shifting Project, „Bulletin for International Taxation” 2016, nr 11, s. 8.

${ }^{21} \mathrm{H}$. Ault, W. Schön, S. Shay, Base Erosion and Profit Shifting: a Roadmap for Reform, „Bulletin for International Taxation” 2014, nr 6-7, s. 275. 
b) prace mające na celu zapobieżenie podwójnemu nieopodatkowaniu (punkt 2 - hybrydyzacja, punkt 3 - regulacje CFC, punkt 4 - niedostateczna kapitalizacja, punkt 5 - szkodliwa konkurencja podatkowa, oraz punkt 6 - nadużycie umów o unikaniu podwójnego opodatkowania);

c) prace mające na celu przywrócenie prawa do opodatkowania dla państwa w którym prowadzona jest działalność gospodarcza (punkt 7 - unikanie statusu stałego zakładu, punkty 8-10 - ceny transferowe);

d) prace dotyczące transparentności podatkowej oraz rozwiązywania sporów (punkt 11 - monitorowanie BEPS, punkt 12 - sprawozdawczość, punkt 13 - dokumentacja cen transferowych, oraz punkt 14 - rozwiązywanie sporów) oraz

e) prace dotyczące wielostronnej konwencji do zmiany umów o unikaniu podwójnego opodatkowania (punkt 15).

Plan Działań OECD powtarza zasadniczo idee przewodnie pierwotnie przedłożone w Raporcie OECD na temat BEPS, czyli że luki w interakcji pomiędzy regulacjami podatkowymi poszczególnych państw, postanowieniami umów o unikaniu podwójnego opodatkowania w stosunku do wielostronnych porozumień oraz wzrost znaczenia cyfrowej gospodarki z przeniesieniem głównych funkcji biznesowych prowadziły to osłabienia międzynarodowego systemu podatkowego. Plan Działań OECD przyznaje, $\mathrm{iż} \mathrm{w}$ wielu okolicznościach istniejące regulacje prawa wewnętrznego oraz postanowienia umów o unikaniu podwójnego opodatkowania prowadzą do właściwego rezultatu, ale stawia tezę, iż w przypadku braku skoordynowanego działania $\mathrm{w}$ innych obszarach państwa mogą uciekać się do jednostronnych działań, które z kolei mogą skutkować wzrostem sytuacji podwójnego opodatkowania oraz wzrostem niepewności podatników ${ }^{22}$. W rezultacie, Plan Działań OECD wzywa do podjęcia uzgodnionych, skoordynowanych kroków, które będą stanowić odpowiedź na zjawisko podwójnego nieopodatkowania będącego rezultatem sytuacji, gdy dochód podatkowy jest sztucznie odseparowany od działalności generującej taki dochód. Podsumowując, potencjalną wartością projektu BEPS ma być przede wszystkim podjęcie próby skoordynowania działań podejmowanych przez poszczególne państwa w celu zwalczania takiego zjawiska. Pomimo istnienia rozbieżnych interesów w obszarach objętych Planem

${ }^{22}$ H. Ault, B. Arnold, Protecting the Tax Base of Developing Countries: An Overview, „Papers on Selected Topics in Protecting the Tax Base of Developing Countries” 2013, nr 1, s. 7. 
Działania OECD wydaje się, iż za duże osiągnięcie uznać należałoby nawet uzgodnienie i wzajemne stosowanie dobry praktyk w tych obszarach ${ }^{23}$.

Jedną z przyczyn skali zjawiska BEPS jest słabość strukturalna regulacji CFC obowiązujących w obecnym kształcie w państwach rozwiniętych, co nie zapobiega przekierowywaniu dochodu do spółek CFC. Chociaż wskazuje się, iż kluczową przyczyną BEPS są przede wszystkim „słabe” regulacje cen transferowych ${ }^{24}$, to regulacje CFC oraz inne reżimy przeciwdziałające odroczeniu opodatkowania wprowadzone w wielu krajach, nie zwalczają zjawiska BEPS w sposób kompleksowy ${ }^{25}$. W piśmiennictwie podnoszono, iż punkt 3 z Planu Działań OECD poświęcony regulacjom CFC jest nakierowany wyłącznie na ochronę interesów fiskalnych państw rezydencji, podczas gdy inne punkty projektu BEPS są dedykowane zabezpieczeniu interesów fiskalnych państw źródła, bądź zarówno interesów państw rezydencji i źródła ${ }^{26}$. Tymczasem, samo OECD zwracało uwagę, że pomimo faktu, iż regulacje CFC prowadzą w swoim założeniu do uwzględniania dochodu w państwie rezydencji osoby kontrolującej, to takie regulacje mogą osiągnąć również pozytywny efekt "rozlania” (ang. spill-over effect) względem państw źródła, ponieważ na skutek zastosowania regulacji CFC podatnicy utracą całkowicie bądź w znacznej mierze zachętę do transferu dochodu z państw źródła do państw trzecich o niskim poziomie opodatkowania, gdy takiej oszczędności podatkowej towarzyszyć będzie obowiązek podatkowy na podstawie reżimu CFC obowiązującego w państwie podatnika (osoby kontrolującej). Ten ostatni aspekt dobrze ilustruje przykład amerykańskiego koncernu Google, gdzie „liberalne” amerykańskie regulacje CFC skutkowały obniżoną efektywną stawką opodatkowania nie tylko w Stanach Zjednoczonych, ale nie zapobiegały transferowi dochodu do Irlandii, pomimo faktu, iż Irlandia w tych strukturach nie powinna być kwalifikowana jako państwo źródła, ale właśnie jako państwo trzecie o niskim poziomie opodatkowania do którego transferowany był dochód z państw źródła, przeważnie innych

${ }^{23} \mathrm{~J} . \mathrm{Hey}$, Base Erosion and Profit Shifting and Interest Expenditure, „Bulletin for International Taxation" 2014, nr 6-7, s. 332.

${ }^{24}$ Y. Brauner, BEPS: an Interim Evaluation, „World Tax Journal” 2014, nr 1, s. 22.

${ }^{25}$ Plan Działań OECD, s. 16.

26 S. Picciotto, Can the OECD Mend the International Tax System?, „Tax Notes International", 2013, $\mathrm{nr} 71$, s. 1107; H. Rosenbloom, J. Brothers, Reflections on the Intersection of U.S. Tax Treaty Policy, U.S. Tax Reform, and BEPS, „Tax Notes International” 2015, nr 78, s. 764. 
państw europejskich ${ }^{27}$. Można więc uznać, że Plan Działań OECD wprowadził całkowicie nową dyrektywę w konstrukcji regulacji CFC poprzez rozszerzenie zakresu ochronnego tychże regulacji o podstawę opodatkowania państw źródła. Celem punktu 3 z Planu Działań OECD było więc zaprojektowanie efektywnych regulacji CFC wzmacniających system globalnego opodatkowania rezydenta podatkowego od dochodu, który nie jest opodatkowany w państwie źródła poprzez ograniczenie zwolnienia lub odroczenia opodatkowania ${ }^{28}$.

\subsection{Obszary oddziaływania regulacji CFC}

Ostateczne raporty BEPS, stanowiące realizację zobowiązań podjętych w ramach Planu Działań OECD, zostały opublikowane przez OECD w dniu 5 października 2015 r. ${ }^{29}$ Efekt prac dotyczących regulacji CFC przyjął formę luźnych rekomendacji w zakresie konstrukcji modelowego reżimu CFC, czyli formy nieobligującej państw uczestniczących w pracach projektu BEPS, podczas gdy wynik innych prac sfinalizował się $\mathrm{w}$ formie minimalnego standardu (przykładowo Punkt 5 oraz Punkt 6) czy też w formie wspólnego podejścia (przykładowo Punkt 2 oraz Punkt 4).

Jak zasugerowano w Planie Działań OECD oraz potwierdzono w Raporcie BEPS nr 3 rekomendacje co do kształtu regulacje CFC miały zostać skoordynowane z rekomendacjami dotyczącymi pozostałych obszarów zwalczania zjawiska BEPS. W tym kontekście OECD wymieniło obszar dotyczący gospodarki cyfrowej (punkt 1 Planu Działań), regulacji anty-hybrydowych (punkt 2 Planu Działań), potrącalności odsetek oraz innych zbliżonych płatności finansowych (punkt 4 Planu Działań), szkodliwych praktyk podatkowych punkt 5 Planu Działań) oraz regulacji cen transferowych (punkty 8-10 Planu Działań) ${ }^{30}$. Poniżej zostanie przeanalizowane, czy i w jakim stopniu OECD wywiązało się z powyższego zobowiązania, przy czym autor odniesie kwestię regulacji CFC również do tematyki zwalczania nadużycia umów o unikaniu podwójnego opodatkowania (punkt 6 Planu Działań), co zostało pominięte przez OECD.

${ }^{27}$ Y. Brauner, op. cit., s. 22.

${ }^{28}$ R. Avi-Yonah, Full Circle? The Single Tax Principle, BEPS and the New US Model, „Public Law and Legal Theory Research Paper Series", 2015, nr 480, s. 13.

${ }^{29} \mathrm{http}$ ://www.oecd.org/ctp/beps-2015-final-reports.htm.

${ }^{30}$ OECD/G20 Base Erosion and Profit Shifting Project, Designing Effective Controlled Foreign Company Rules ACTION 3: 2015 Final Report, 2015, dalej: Raport BEPS nr 3, pkt 4. 
5. Regulacje CFC w świetle punktu 1 Planu Działań

Raport BEPS nr 1 został poświęcony opodatkowaniu gospodarki cyfrowej (ang. digital economy) ${ }^{31}$. Digitalizacja gospodarki przejawia się w dematerializacji procesów produkcji, fragmentaryzacji funkcji, tworzenia globalnych łańcuchów dostawy oraz zwiększonej roli sektora usługowego $^{32}$. Dochód ze sprzedaży tzw. towarów i usług cyfrowych jest szczególnie narażony na transfer do spółek położonych w państwach o niskim poziomie opodatkowania $z$ uwagi na fakt, iż przy ich wytworzeniu wykorzystywane są łatwo przenoszalne wartości niematerialne i prawne, a sama sprzedaż takich towarów i usług przy wykorzystaniu środków komunikacji na odległość, przede wszystkim Internetu, nie wymaga zaangażowania znacznej ilości pracowników ${ }^{33}$. Nakłada się na to obiektywna trudność w stwierdzeniu, gdzie usługi są konsumowane lub wykonywane, co może być istotne z perspektywy regulacji CFC w części w jakiej takie regulacje kwalifikują jako dochód CFC dochód „spółek fakturowych”, gdy przykładowo do wyświadczenia przedmiotowych usług są wykorzystywano video-konferencje lub gdy usługa polega na dostępie do bazy danych, albo zachodzi niemożność stwierdzenia gdzie towar został dostarczony, jeżeli klient nabywa oprogramowanie za pomocą Internetu ${ }^{34}$. Zmiany modelów biznesowych związanych z gospodarką cyfrową dobrze ilustruje przykład produkcji oprogramowania, gdy zamiast wytwarzania takiego produktu / usługi w państwie położenia podatnika (osoby kontrolującej), taka produkcja i dystrybucja dokonywana jest zdalnie na odległośćc ${ }^{35}$. W tym przykładzie spółka położona w raju podatkowym staje się odpowiedzialna za produkcję i sprzedaż oprogramowania, przy czym produkcja jest prowadzona zdalnie przez Internet przez pracowników którzy przebywają

${ }^{31}$ OECD/G20 Base Erosion and Profit Shifting Project, Addressing the Tax Challenges of the Digital Economy, Action 1 - 2015 Final Report, 2015, dalej: Raport BEPS nr 1.

32 A. Oguttu, OECD's Action Plan on Tax Base Erosion and Profit Shifting: Part 2 - a Critique of Some Priority OECD Actions from an African Perspective - Addressing Excessive Interest Deductions, Treaty Abuse and the Avoidance of The Status of a Permanent Establishment, „Bulletin for International Taxation” 2016, nr 6, s. 354.

${ }^{33} \mathrm{Ch}$. Panayi, Advanced Issues in International and European Tax Law, Oxford 2015, s. 53.

${ }_{34}$ R. Doernberg, L. Hinnekens, Electronic Commerce and International Taxation, Hague 1999, s. 223.

${ }^{35}$ P. Glicklich, A. Leitner, U.S. Taxation of E-commerce under Subpart F-Missing Pieces Leave Uncertainty, „Bulletin for International Taxation”, 2001, nr 9-10, s. 511. 
w państwie osoby kontrolującej (ich relokacja do spółki z raju podatkowego ma charakter „papierowy”), a sprzedaż również jest dokonywana $z_{\text {zalnie }}^{36}$. Jak pokazuje doświadczenie Stanów Zjednoczonych, podatnik może skutecznie wywodzić, iż spółka taka prowadzi aktywną działalność gospodarczą wymykającą się odziaływaniu regulacji CFC ${ }^{37}$. Podmioty prowadzące tego typu działalność nie są więc efektywnie objęte, w znacznej części przypadków, regulacjami $\mathrm{CFC}^{38}$. W konsekwencji, przedsiębiorstwa międzynarodowe z tytułu prowadzenia działalności w zakresie gospodarki cyfrowej uiszczają niewysokie podatki w państwie położenia spółki CFC oraz unikają opodatkowania w państwie źródła oraz państwie podatnika (osoby kontrolującej) ${ }^{39}$.

Drugim problematycznym zagadnieniem, oprócz zagadnienia związanego z lokalizacją czynności prowadzących do powstania dochodu zagranicznej jednostki, jest kategoryzacja dochodu spółki CFC w świetle ustawodawstwa państwa osoby kontrolującej ${ }^{40}$, gdy przykładowo sprzedaż oprogramowania jest kwalifikowana albo jako dochód ze sprzedaży prawa majątkowego albo jako należność licencyjna w zależności od transferu albo jego braku wiązki praw do reprodukcji, dystrybucji czy też modyfikacji oprogramowania ${ }^{41}$. Na tle przyjętej kategorii zróżnicowane mogą być dodatkowe kryteria których spełnienie prowadzić będzie do powstania dochodu CFC. Odwołując się ponownie do przykładu amerykańskich regulacji CFC które jako pierwsze musiały „zmierzyć” się z wyzwaniami gospodarki cyfrowej, takim dodatkowym kryterium może być status kontrahenta, gdy przykładowo dochód ze sprzedaży będzie objęty regulacjami CFC jeżeli powstaje $z$ tytułu transakcji z podmiotem powiązanym, podczas gdy należność licencyjna jako dochód pasywny jest per definitionem objęta regulacjami $\mathrm{CFC}^{42}$.

${ }^{36}$ D. Pinto, Exclusive Source or Residence-Based Taxation - Is a New and Simpler World Tax Order Possible?, „Bulletin for International Taxation” 2007, nr 7, s. 283

37 D. Pinto, A Proposal to Reform Income Anti-tax-Deferral Regimes, „Australian Journal of Taxation" 2009, nr 12, s. 60.

${ }^{38}$ Raport BEPS nr 1, pkt 235.

${ }^{39}$ J. English, BEPS Action 1: Digital Economy - EU Law Implications, „British Tax Review" 2015, nr 3, s. 3.

${ }^{40}$ Treasury Department Office of Tax Policy, The Deferral of Income Earned through US Controlled Foreign Corporations: a Policy Study, 2000, s. 76.

${ }^{41}$ N. Maquire, S. Anolik, Subpart F and Source of Income Issues in E-commerce, „Tax Notes" 2000, nr 89, s. 1937.

${ }^{42}$ P. Glicklich, A. Leitner, U.S. Taxation of E-commerce..., s. 509. 
OECD w Raporcie BEPS nr 1 nie przewiduje dodatkowych rekomendacji co do kształtu regulacji CFC w kontekście gospodarki cyfrowej odwołując się do przedstawionych koncepcji w ramach Raportu BEPS nr 3, w szczególności odnośnie do mechanizmów pozwalających określić dochód spółki CFC podlegający przypisaniu do opodatkowania „w rękach” osoby kontrolującej, czyli tzw. podejścia kategorialnego, podejścia nadmiernych zysków oraz podejścia treści ${ }^{43}$. W przypadku gospodarki cyfrowej „ostrze” regulacji CFC powinno być wymierzone w dochód $\mathrm{z}$ własności intelektualnej wytransferowanej do spółki w państwie o niskim poziomie opodatkowania i/lub gdy spółka taka uzyskuje dochód ze sprzedaży na odległość towarów i usług, do powstania których taka własność jest wykorzystywana. W piśmiennictwie sugeruje się, iż najbardziej preferowanym przez OECD oraz państwa członkowskie rozwiązaniem w zakresie określenia dochodu jest mechanizm treści $\mathrm{w}$ wersji podejścia pracowników oraz placówki, gdzie w przypadku najbardziej problematycznego dochodu z własności intelektualnej wymagane jest by spółka CFC (1) posiadała pracowników z właściwymi kompetencjami którzy mogą prowadzić badania i rozwój oraz (2) dysponowała lokalem i wyposażeniem do wytworzenie własności intelektualnej ${ }^{44}$. W tym kontekście trzeba również wspomnieć, iż na potrzeby definiowania dochodu CFC OECD rozważa również posługiwanie się przesłanką powiązania pomiędzy spółką CFC a innym podmiotem $\mathrm{z}$ grupy, w efekcie czego dochód z własności intelektualnej wytworzonej w ramach umów o podział kosztów także może zostać objęty regulacjami CFC.

\section{Regulacje CFC w świetle punktu 2 Planu DziaŁań}

O postanowieniach zwalczających hybrydyzację w kontekście regulacji CFC można mówić zarówno odnośnie do takich wytycznych zawartych w Raporcie BEPS nr 2 który został poświęcony stricte hybrydyzacji ${ }^{45}$, jak i wytycznych zawartych w Raporcie BEPS nr 3 który został poświęcony stricte regulacjom CFC. Różnica między tymi przypadkami sprowadza się do tego, iż hybrydyzacja na potrzeby Raportu BEPS nr 3 to szczególna jej forma, która różni się od przykładów hybrydyzacji z Raportu BEPS nr 2

${ }^{43}$ Raport BEPS nr 1, pkt 236.

${ }^{44}$ J. English, op. cit., s. 7.

${ }^{45}$ OECD/G20 Base Erosion and Profit Shifting Project, Neutralising the Effects of Hybrid Mismatch Arrangements Action 2: 2015 Final Report, 2015, dalej: Raport BEPS nr 2. 
tym, iż ta pierwsza zakłada niedopasowanie klasyfikacyjne pomiędzy prawem państwa osoby kontrolującej (państwem stosującym regulacje CFC) oraz prawem innego państwa, podczas gdy przykłady hybrydyzacji z Raportu BEPS nr 2 dotyczą niedopasowania klasyfikacyjnego pomiędzy prawem państw innych niż państwo osoby kontrolującej. W tej ostatniej relacji państwo osoby kontrolującej jest w pewnym sensie państwem trzecim, które może wspomóc zwalczanie zjawiska BEPS zachodzącego w relacji pomiędzy tymi innymi państwami.

\subsection{Hybrydyzacja objęta raportem BEPS nr 2}

Raport BEPS nr 2 dotyczy neutralizacji niepożądanych w ocenie OECD skutków instrumentów oraz podmiotów hybrydowych wykorzystywanych w operacjach transgranicznych. Chodzi między innymi o przypadki gdy na skutek różnic w ustawodawstwach co najmniej dwóch państw regulujących kwalifikację takich instrumentów bądź jednostek dochodzi do tzw. arbitrażu podatkowego, czyli sytuacji gdy w jednym państwie płatność stanowi koszt podatkowy, a w państwie odbiorcy taka płatność nie stanowi dochodu podatkowego ${ }^{46}$. Ten efekt może zostać osiągnięty jeżeli w jednym państwie instrument zostanie zakwalifikowany jako instrument dłużny pozwalający rozpoznać koszt podatkowy z tytułu płatności odsetkowej, podczas gdy w drugim państwie ten sam instrument zostanie ujęty jako wkład kapitałowy uprawniający do rozpoznania zwolnionej od opodatkowania dywidendy. Jest to jeden z podstawowych przykładów hybrydyzacji określany mianem hybrydowego instrumentu finansowego (ang. hybrid financial instrument) skutkującego zjawiskiem potrącenie i braku przypisania (ang. deduction/non-inclusion) ${ }^{47}$.

OECD wskazuje, iż w sytuacji, gdy płatność zostanie opodatkowana na podstawie regulacji CFC obowiązujących w państwie trzecim (państwie osoby kontrolującej), wówczas zjawisko niepożądanej hybrydyzacji zostanie wyeliminowane, czyli potrąceniu w jednym państwie będzie towarzyszyć przypisanie i opodatkowanie w drugim państwie (chociaż w państwie innym niż państwo odbiorcy płatności) i w rezultacie rekomendacje zawarte w Raporcie OECD

${ }^{46}$ M. Helminem, EU Law Compatibility of BEPS Action 2: Neutralising the Effects of Hybrid Mismatch Arrangements, „British Tax Review” 2015, nr 3, s. 1.

${ }^{47}$ A. Dourado, Aggressive Tax Planning in EU Law and in the Light of BEPS: The EC Recommendation on Aggressive Tax Planning and BEPS Actions 2 and 6, „Intertax” 2015, nr 1, s. 45. 
BEPS nr 2 mające na celu wyłączenie potrącalności płatności nie będą musiały być wdrażane $\mathrm{w} \dot{z} y$ cie $^{48}$. Takie wyłączenie jest jednak obwarowane zastrzeżeniem, iż opodatkowanie na podstawie regulacji CFC musi mieć charakter efektywny oraz pełny, czyli według podstawowej stawki podatku dochodowego obowiązującej w państwie osoby kontrolującej ${ }^{49}$. Przedmiotowa rekomendacja jest o tyle zaskakująca, iż historycznie to państwo rezydencji musiało uwzględniać we własnym ustawodawstwie czynnik w postaci ewentualnego poziomu opodatkowania obowiązującego w państwie źródła, przykładowo na potrzeby krajowych przepisów dotyczących kredytu podatkowego, lub właśnie regulacji CFC. Raport BEPS nr 2 w pewnym sensie odwraca ten paradygmat sugerując, iż to państwo źródła powinno zacząć uwzględniać ewentualne opodatkowanie na mocy regulacji CFC obowiązujących w państwie rezydencji osoby kontrolującej. W rezultacie, państwo źródła powinno wyłączyć lub ograniczyć potrącalność podatkową danej płatności wyłącznie w stopniu w jakim taka płatność nie została uwzględniona w „normalnym dochodzie” (ang. ordinary income), czy to w państwie bezpośredniego odbiorcy które zaprzeczyło wyłączeniu od opodatkowania, czy też w państwie osoby kontrolującej na podstawie regulacji CFC. Od strony praktyczno-politycznej taka rekomendacja spotkała się z krytyką w świetle faktu, iż państwa źródła to często państwa rozwijające się, które nie dysponują rozwiniętym aparatem skarbowym, który mógłby dokonywać analizy konsekwencji podatkowych do których dochodzi w państwach rozwiniętych ${ }^{50}$.

OECD pozostawia do decyzji poszczególnych państw czy będą „honorować" na potrzeby własnych regulacji anty-hybrydowych opodatkowanie dokonane przez państwo trzecie na podstawie regulacji CFC obowiązujących w tym państwie trzecim. Tymczasem w doktrynie zgłaszany był postulat zakładający odwróconą kolejność oddziaływania, tak by to ewentualnie państwo osoby kontrolującej rezygnowało $\mathrm{z}$ opodatkowania na podstawie regulacji CFC jeżeli inne państwo zastosuje regulacje anty-hybrydowe celem zwalczenia zjawiska BEPS ${ }^{51}$. W piśmiennictwie podnosi

${ }^{48}$ S. Shay, J. Fleming, R. Peroni, Designing a 21st Century Corporate Tax - An Advance US Minimum Tax on Foreign Income and Other Measures to Protect the Base, „Florida Tax Review” 2015, nr 9, s. 699.

${ }^{49}$ Raport BEPS nr 2, pkt 36-40.

${ }^{50}$ P. Harris, Neutralizing Effects of Hybrid Mismatch Arrangements, [w:] A. Trepelkov, H. Tonino, D. Halka (red.), United Nations Handbook on Selected Issues in Protecting the Tax Base of Developing Countries, New York 2017, s. 279.

${ }^{51}$ G. Maisto, Controlled Foreign Company Legislation, Corporate Residence and AntiHybrid Arrangement Rules, „Bulletin for International Taxation” 2014, nr 6-7, s. 328. 
się jednak, iż w powyższych okolicznościach brakuje wyraźnej hierarchizacji pomiędzy rekomendacjami z Raportu OECD BEPS nr 2 oraz Raportu BEPS nr 3, czyli pomimo faktu, że OECD przyznaje, iż zastosowanie regulacji CFC wyklucza potrzebę zastosowania "mechanizmu obronnego" przewidzianego w Raporcie BEPS nr 2, to nie wskazuje ono expressis verbis który mechanizm, tj. regulacje CFC czy też rozwiązanie antyhybrydowe $\mathrm{z}$ Raportu BEPS nr 2, powinno mieć pierwszeństwo w zastosowaniu ${ }^{52}$. Brak skoordynowania proponowanych regulacji może prowadzić do niepożądanego zjawiska podwójnego opodatkowania, gdy państwo położenia spółki CFC zakaże potrącalności podatkowej płatności, a państwo osoby kontrolującej nakaże uwzględnić taką płatność na zasadzie przypisania wynikającego z regulacji $\mathrm{CFC}^{53}$. Nakłada się na to specyfika tych ostatnich regulacji, które znajdują zastosowanie jedynie w stosunku do osób kontrolujących, którzy spełnią właściwe kryterium kontroli. Innymi słowy, wyeliminowanie hybrydyzacji - przy założeniu, że opierałoby się ono na zastosowaniu regulacji CFC - byłoby uzależnione od statusu udziałowca kontrolowanej spółki zagranicznej jako osoby kontrolującej ${ }^{54}$.

Przykładem, który całkowicie nie doczekał się natomiast komentarza ze strony OECD, jest przypadek, gdy państwo osoby kontrolującej jest jednocześnie państwem, które może być uprawnione do zastosowania tzw. drugi linii obrony z rekomendacji antyhybrydowych, czyli opodatkować przychodzącą płatność w sytuacji, gdy państwo źródła nie wyłączy jej potrącalności podatkowej. Gdy dochodzi do tożsamości osoby kontrolującej oraz odbiorcy płatności, z teoretycznego punktu widzenia, państwo osoby kontrolującej może dokonać wyboru pomiędzy mechanizmem obronnym z którego woli skorzystać, tj. reguły anty-hybrydowej czy też regulacji $\mathrm{CFC}^{55}$. Jeden $\mathrm{z}$ komentatorów sugeruje, $\mathrm{i} \dot{z}$ - podobnie jak przy relacji regulacji CFC z regulacjami cen transferowych - tak w relacji z regulacjami anty-hybrydowymi z Raportu BEPS nr 2 regulacje CFC mają charakter

${ }^{52} \mathrm{Ch}$. Kahlenberg, The Interplay between the OECD Recommendations of Actions 2 and 3 Regarding Hybrid Structures, „Intertax” 2016, nr 4, s. 321-322.

${ }^{53}$ M. Kane, The Role of Controlled Foreign Company Legislation in the OECD Base Erosion and Profit Shifting project, "Bulletin for International Taxation” 2014, nr 6-7, s. 325.

${ }^{54}$ M. Schler, BEPS Action 2: Ending Mismatches on Hybrid Instruments, Part 2, „Tax Notes International" 2014, nr 75, s. 571.

${ }^{55}$ O. Popa, Past, Present and Future of Tax Structuring Using Hybrid Entity Mismatches, [w:] M. Cotrut (red.), International Tax Structures in the BEPS Era: An Analysis of Antiabuse Measures, Amsterdam 2015, s. 171. 
uzupełniający/wspomagający ${ }^{56}$, co zdaje się potwierdzać OECD w Raporcie BEPS nr 3 stwierdzając, że tylko specyficzna hybrydyzacja, tj. objęta explicite Raportem BEPS nr 3, nie zostanie objęta Raportem BEPS nr $2^{57}$.

Raport BEPS nr 2 grupuje przykłady hybrydyzacji nie wymieniając jednak wszystkich ich form. Tymi grupami są, dodatkowo do ww. hybrydowego instrumentu finansowego, między innymi transparentna płatność hybrydowa (ang. disregarded hybrid payment), odwrócona hybryda (ang. reverse hybrid), potrącalna płatność hybrydowa (ang. deductible hybrid payment) czy też zaimportowane niedopasowanie (ang. imported mismatch). Autor nie opisuje szczegółowo powyższych postaci hybrydyzacji $\mathrm{z}$ uwagi na fakt, iż OECD nie zawarło w Raporcie BEPS nr 2 żadnych rekomendacji co do kształtu regulacji CFC wskazując jedynie przykłady ${ }^{58}$, gdzie regulacje CFC mogą per se wyeliminować lub przynajmniej ograniczyć negatywne skutki różnic w systemach prawnych innych państw, tj. wskazując na pomocniczy efekt tychże regulacji na wzór opisanego powyżej hybrydowego instrumentu finansowego ${ }^{59}$. Kształt regulacji CFC zawarty w Raporcie BEPS nr 3 pozostawałby w tym zakresie niezmieniony.

\subsection{Hybrydyzacja objęta raportem BEPS nr 3}

OECD sugeruje w Raporcie BEPS nr 3 uzupełnienie regulacji CFC o rozwiązania wyłączające tzw. hybrydowe niedopasowanie podmiotowości (ang. hybrid mismatch of entities) oraz tzw. hybrydowe niedopasowanie umów/transakcji (ang. hybrid mismatch of arrangements), które prowadzą do odmiennej klasyfikacji podmiotów oraz instrumentów w przynajmniej dwóch państwach, czyli, co najmniej, w państwie osoby kontrolującej oraz w państwie spółki CFC ${ }^{60}$. Należy podkreślić, iż celem takich uzupełniających wytycznych byłoby nie tyle bezpośrednie zapobieżenie erozji podstawy opodatkowania państwa osoby kontrolującej, ale innego państwa, przede wszystkim państwa źródła (ang. foreign-to-foreign stripping). Powyższymi rekomendacja OECD próbuje zapobiec negatywnym konsekwencjom, gdy dana jednostka (z państwa źródła) jest klasyfikowana jako transparentna podatkowo w świetle prawa państwa stosującego regulacje CFC, w efekcie

${ }^{56}$ A. Dourado, The Role of CFC Rules..., s. 349.

${ }^{57}$ Raport BEPS nr 3, pkt 31.

${ }^{58}$ Raport BEPS nr 2, przykład nr 1.24, przykład 4.3 oraz przykład 6.4.

${ }^{59}$ J. Lüdicke, „Tax Arbitrage” with Hybrid Entities: Challenges and Responses, „Bulletin for International Taxation" 2014, nr 6-7, s. 316.

${ }^{60}$ Raport BEPS nr 3, pkt 29. 
czego jej dochód podlega opodatkowaniu „w rękach” innej zależnej jednostki, która $\mathrm{z}$ kolei podlega efektywnie zerowemu lub niskiemu opodatkowaniu (z państwa o niskim poziomie opodatkowania). Innymi słowy, chodzi tutaj o przypadki gdy prawo wewnętrzne państwa osoby kontrolującej traktuje zagraniczne podmioty jako fiskalną jedność, co przekłada się na nieefektywność własnych regulacji CFC które "gubią" międzygrupowe płatności pasywne poprzez przyjęcie, że są one dokonywane w ramach tego samego podmiotu, w związku z czym nie generują dochodu CFC. Chociaż rozwiązanie anty-hybrydowe uzupełniające regulacje CFC nie wyeliminuje w pełni zjawiska transferu dochodu do państw o niskim poziomie opodatkowania, to może przyczynić się do jego istotnego ograniczenia ${ }^{61}$.

Omawiana powyżej sytuacja ma miejsce, gdy przykładowo w pionowej strukturze właścicielskiej pomiędzy osobą kontrolującą (spółką A) a jej spółką zależną z państwa o wysokim poziomie opodatkowania (spółką C) umiejscowiona zostanie dodatkowa spółka - spółka CFC - położona w państwie o niskim poziomie opodatkowania (spółka B). Jeżeli struktura zostanie tak zaplanowana by spółka zależna z państwa o wysokim poziomie opodatkowania została zakwalifikowana jako transparentna podatkowo w świetle przepisów państwa osoby kontrolującej (spółka C zostałaby uznana za transparentną podatkowo z perspektywy państwa $A$ ), wówczas płatność od spółki zależnej (spółki C) do spółki CFC (spółki B) może zostać uznana za koszt podatkowy w tym pierwszym państwie, gdy tymczasem w świetle regulacji CFC państwa osoby kontrolującej (państwa A) obydwie spółki zostaną zakwalifikowane jako jeden podmiot, w efekcie czego dla celów regulacji CFC płatność pomiędzy nimi będzie neutralna podatkowo, tj. nie wygeneruje dochodu dla celów CFC po stronie spółki CFC (spółki B). Taka płatność nie będzie jednocześnie opodatkowana w sposób wystarczający w państwie $B$, gdyż państwo to albo nie nakłada podatku w ogóle, albo nakłada niskie opodatkowanie.

W powyższych okolicznościach OECD postuluje by państwo osoby kontrolującej (państwo A) przy wykorzystaniu regulacji CFC niejako wspomogło państwo położenia spółki CFC (państwo C) poprzez uwzględnienie takiej płatności jako dochodu na potrzeby własnych regulacji CFC. Co istotne, powyższa sytuacja nie będzie objęta rekomendacjami w zakresie Raportu BEPS nr 2, gdyż nie dochodzi tutaj do zjawiska hybrydyzacji na

${ }^{61}$ M. Durst, Self-help and Altruism: Exploring the Problem of Tax Base Erosion in Developing Countries, Bloomberg BNA, „Tax Management Transfer Pricing Report” 2014, nr 228, s. 4. 
gruncie przepisów państwa spółki zależnej oraz państwa spółki $\mathrm{CFC}^{62}$. Do hybrydyzacji dochodzi „jedynie” w rozumieniu przepisów państwa osoby kontrolującej (państwa A), gdzie spółka zależna z państwa $\mathrm{C}$ jest kwalifikowana jako podmiot transparentny podatkowo.

\section{Zmodyfikowana reguła niedopasowania hybrydowego}

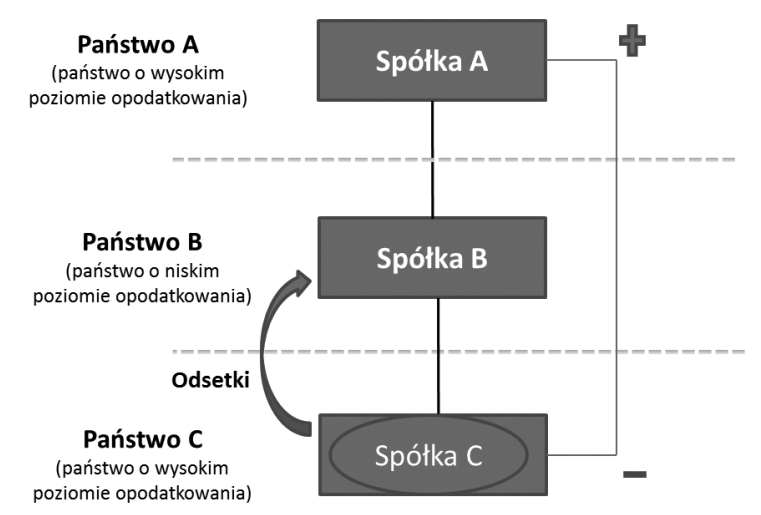

Źródło: opracowanie OECD ${ }^{63}$.

Analogiczny do powyższego rezultat może zostać osiągnięty, gdy zamiast hybrydowego niedopasowania podmiotowości dojdzie do hybrydowego niedopasowania instrumentu, czyli przykładowo gdy z perspektywy państwa stosującego regulacje CFC (państwa A) płatność pomiędzy dwoma zagranicznymi podmiotami będzie traktowana jako płatność dywidendy zwolniona od opodatkowania a według prawa państwa jednostki wypłacającej (państwa C) taka płatność będzie potrącalną dla celów podatkowych płatnością odsetkową. Taki konflikt byłby pochodną ujęcia środków przekazanych pomiędzy tymi dwoma zagranicznymi podmiotami jako (1) wkładu kapitałowego w rozumieniu prawa państwa stosującego regulacje CFC generującego zwolnioną od opodatkowania dywidendę, oraz (2) pożyczki w rozumieniu prawa państwa położenia spółki dokonującej płatności generującej potrącalne dla celów podatkowych odsetki. Jeszcze innym przykładem omawianego niedopasowania jest sytuacja,

${ }^{62} \mathrm{Ch}$. Kahlenberg, The Interplay between the OECD Recommendations of Actions 2 and 3 Regarding Hybrid Structures, „Intertax” 2016, nr 4, s. 318.

${ }^{63}$ Raport BEPS nr 3, pkt 31. 
gdy w świetle przepisów państwa stosującego regulacje CFC dotyczących rezydencji podatkowej okaże się, iż obydwa zagraniczne podmioty są rezydentami tego samego państwa a regulacje CFC przewidują wyłączenie z dochodu CFC płatności dokonywanych w ramach jednego państwa ${ }^{64}$. Taki przypadek dotyczy konfliktu w obszarze zasad dotyczących rezydencji podatkowej.

W celu wyłączenia negatywnych konsekwencji konfliktów kwalifikacyjnych, o których mowa powyżej - związanych z niedopasowaniem praw dwóch różnych państw - poprzez rozszerzenie zakresu oddziaływania regulacji CFC o tzw. zmodyfikowaną regułę niedopasowania hybrydowego (ang. modified hybrid mismatch rule), tj. by regulacje CFC wywoływały skutek również $\mathrm{w}$ formie zapobieżenia erozji podstawy opodatkowania także tych innych państw, OECD zaproponowało ogólne wytyczne w zakresie skoordynowanego podejścia do międzygrupowych płatności w wersji szerszej oraz węższej, z rekomendacją na przyjęcie wersji szerszej. W ramach wersji szerszej, międzygrupowa płatność powinna stanowić dochód CFC jeżeli dana płatność (1) nie stanowi dochodu CFC zgodnie $\mathrm{z}$ dotychczasowym brzmieniem regulacji CFC, oraz (2) stanowiłaby dochód CFC, gdyby państwo stosujące regulacje CFC zakwalifikowałoby podmiot albo płatność w analogiczny sposób jak państwo położenia podmiotu wypłacającego lub państwo położenia odbiorcy. Wersja węższa, przedstawiona wyłącznie w roboczej wersji Raportu BEPS nr 3 - ale już nie w jego finalnej wersji - zawierała dodatkowy warunek w postaci erozji podstawy opodatkowania przez płatność, tj. bycia odliczalnym w państwie podmiotu wypłacającego oraz bycia nieopodatkowanym lub nisko opodatkowanym w państwie odbiorcy.

Zwraca uwagę, iż wersja szersza zmodyfikowanej reguły niedopasowania hybrydowego (nie wspominając o wersji węższej) może wymagać czasochłonnej oraz niejednokrotnie skomplikowanej analizy. Najbardziej problematycznym aspektem wdrożenia tej reguły jest porównanie kwalifikacji podmiotów oraz porozumień dokonanej w państwie podmiotu wypłacającego i państwie odbiorcy z kwalifikacją tych podmiotów i porozumień którą należy dokonać w państwie osoby kontrolującej. Dokonanie takiego porównania wymagałoby znajomości prawa tych innych państw. W grę wchodziłyby zasadniczo trzy systemy prawne. Rekomendacja ta wydaje się być ponadto niespójna $\mathrm{z}$ podstawowym założeniem rekomendacji OECD by do wyliczenia dochodu CFC stosować przepisy prawa wewnętrznego państwa osoby kontrolującej. Co gorsza, zastosowanie szerszej wersji

${ }^{64}$ Taki wyjątek przewidują amerykańskie regulacje CFC (Subpart F). 
zmodyfikowanej reguły niedopasowania hybrydowego może prowadzić do podwójnego opodatkowania w sensie ekonomicznym w sytuacji, gdy państwo spółki CFC zastosuje jednocześnie rekomendacje zwalczające hybrydowość z Raportu BEPS nr 2, tj. odmówi potrącalności podatkowej dla płatności odsetkowej. W przeciwieństwie do wersji węższej, wersja szersza reguły niedopasowania nie uzależnia bowiem opodatkowania na podstawie regulacji CFC od tego czy podstawa opodatkowania państwa spółki CFC uległa faktycznej erozji ${ }^{65}$. Wydaje się więc, iż powyższa rekomendacja ma czysto teoretyczny wymiar, gdyż od strony praktycznej nie będzie możliwe jej wdrożenie.

Spotkać można zarzut, iż zmodyfikowana reguła niedopasowania hybrydowego ma w rzeczywistości jedynie na celu wyeliminowanie mechanizmu wyboru podmiotowości obowiązującego w amerykańskim systemie podatkowym (ang. check-the-box rules) ${ }^{66}$, którego - jak podnosi się w piśmiennictwie - żaden racjonalny system podatkowy nie powinien przewidywać6 ${ }^{67}$, a który jak przyznają same amerykańskie władze skarbowe prowadzi do bezpośredniej erozji podstaw opodatkowania innych państw ${ }^{68}$. Przepisy te, znajdujące się poza systematyką per se regulacji CFC, pozwalają amerykańskim osobom kontrolującym na wybór klasyfikacji podatkowej zagranicznych podmiotów na potrzeby amerykańskich przepisów, tj. jako podatników podatku dochodowego albo jako podmiotów transparentnych podatkowo, w oderwaniu od „lokalnej” klasyfikacji podatkowej takich podmiotów. W tym kontekście, prezentuje się wręcz pogląd, iż u podstaw całych rekomendacji OECD w zakresie BEPS leży właśnie chęć wyeliminowania negatywnych skutków amerykańskich regulacji check-the-box ${ }^{69}$ albo że uwzględniwszy ograniczenia wynikające

${ }^{65}$ Ch. Kahlenberg, op. cit., s. 320

${ }^{66}$ A. Athanasiou, BEPS Action 3 (CFC rules): Final CFC Report Leaves Options Open, „Tax Notes International” 2015, nr 80, s. 114.

${ }^{67}$ P. Baker, BEPS Appraisal: Interview with Philip Baker QC, „Journal of International Taxation" 2015, nr 1, s. 32; J. Owens, The Taxation of Multinational Enterprises: An Elusive Balance, „Bulletin for International Taxation” 2013, nr 8, s. 445.

${ }^{68}$ U.S. Joint Committee on Taxation, Present Law and Backgrounds Related to Possible Income Shifting and Transfer Pricing. Scheduled of a Public Hearing before the House Committee on Ways and Means, 2010, s. 123; D. Shaviro, The Two Faces of the Single Tax Principle, „Brooklyn Journal of International Law” 2016, nr 3, s. 1301.

${ }^{69}$ A. Athanasiou, OECD's CFC Rule Draft Likely to Spur Controversy, „Tax Notes International" 2015, nr 78, s. 141; Idem, Lack of Consensus on CFC Rules Likely Here to Stay, „Tax Notes International” 2015, nr 78, s. 208. 
z orzecznictwa TSUE wiążące państwa członkowskie Unii Europejskiej w konstruowaniu regulacji CFC, rekomendacje OECD odnoszące się do zmodyfikowanej reguły niedopasowania hybrydowego są adresowane przede wszystkim do Stanów Zjednoczonych celem naprawy tamtejszego reżimu $\mathrm{CFC}^{70}$. W amerykańskim piśmiennictwie podnosi się natomiast, iż w najbliższej przyszłości nie będzie zgody politycznej na likwidację regulacji check-the-box ${ }^{71}$. Warto nadmienić, iż amerykańskie władze podatkowe bezskutecznie proponowały rozwiązania legislacyjne $\mathrm{w}$ ramach regulacji CFC, które miały ukrócić praktyki związane z hybrydyzacją podmiotów i płatności ${ }^{72}$. Bliższa analiza rekomendacji OECD wskazuje wręcz, że OECD oparło swoje rozwiązanie, chociaż $\mathrm{w}$ formie uproszczonej bo przykładowo bez mechanizmu wyliczania różnicy pomiędzy hipotetyczną efektywną stawką opodatkowania w państwie dokonania płatności oraz efektywną stawką opodatkowania w państwie otrzymania płatności (and. tax disparity rule) ${ }^{73}$, właśnie na propozycji amerykańskich władz podatkowych z $1998 \mathrm{r}^{74}$ Wówczas działanie amerykańskich władz podatkowych zostało skutecznie zablokowane przez amerykański Kongres, który nie zgodził się by Stany Zjednoczone podjęły jednostronne działania chroniące podstawy opodatkowania innych państw ograniczając praktyki optymalizacyjne własnych podatników ${ }^{75}$.

${ }^{70}$ Ch. Panayi, Advanced Issues..., s. 70.

71 Taki project bezskutecznie wniósł m.in. prezydent Obama w 2009 r. - U.S. Department of the Treasury, General Explanations of the Administration's Fiscal Year 2010 Revenue Proposals, 2009, s. 28.

${ }^{72}$ Internal Revenue Service (IRS), Treatment of Hybrid Arrangements under Subpart F (okólnik nr Notice 98-11), 1998; Treatment of Hybrid Arrangements under Subpart F (okólnik nr Notice 98-35), 1998; Guidance under Subpart F Relating to Partnerships and Branches (projekt Rozporządzenia nr TD 8767), 1998; Withdrawal of Guidance under Subpart F Relating to Partnerships and Branches; and Issuance of New Guidance under Subpart $F$ relating to Certain Hybrid Transactions (projekt Rozporządzenia nr REG113909-98), 1999.

${ }^{73}$ Internal Revenue Service, Treatment of Hybrid Arrangements under Subpart F (okólnik nr Notice 98-35), 1998, s. 2.

${ }^{74}$ Internal Revenue Service, Guidance under Subpart F Relating to Partnerships and Branches (projekt Rozporządzenia nr TD 8767), 1998, s. 5-6.

${ }^{75}$ L. Yoder, Subpart F in Turmoil: Low-Taxed Active Income under Siege, „Taxes - The Tax Magazine" 1999, nr 3, s. 153; J. Kuntz, R. Peroni, US International Taxation, Part B Taxation of U.S. Persons with Foreign Activities, B3.04. Subpart F Income (Section 952), WG\&L International Treatises, Thomson Reuters, 2015, książka online, s. 9. 
6.3. Wnioski

Podsumowując, rekomendacje anty-hybrydowe zawarte $\mathrm{w}$ Raporcie BEPS nr 3 należałoby skoordynować z rekomendacjami anty-hybrydowymi zawartymi w Raporcie BEPS nr 2 celem wyeliminowania niezamierzonych przypadków podwójnego opodatkowania w sensie ekonomicznym tej samej wartości. Na marginesie wypada wspomnieć, iż w przeciwieństwie do OECD, w Unii Europejskiej zabrakło nawet rozważań na temat skoordynowania krajowych regulacji CFC, również tych zaimplementowanych na mocy Dyrektywy przeciwko unikaniu opodatkowania ${ }^{76} \mathrm{z}$ regułą anty-hybrydową, która została wprowadzona do Dyrektywy o spółkach matkach i spółkach córkach w 2014 r. ${ }^{77}$

\section{Regulacje CFC w świetle punktu 4 Planu Dziąań}

Raport BEPS nr 4 dotyczy ograniczenia erozji podstawy opodatkowania w drodze potrącalności odsetek oraz innych finansowych płatności o charakterze zbliżonym do odsetek ${ }^{78}$. Raport OECD poświęcony temu punktowi przedstawia rekomendacje w zakresie wprowadzenia do prawa wewnętrznego instrumentów ograniczających potrącalność podatkową odsetek. W tym kontekście do dobrych praktyk należy w szczególności wyłączenie z kosztów podatkowych tej części kosztu odsetkowego netto odczytywanego jako różnica pomiędzy kosztem odsetkowym a przychodem odsetkowym, która stanowi nadwyżkę ponad kwotę wyliczoną jako określony procent, w przedziale od 10\% do 30\% wartości zysków przed odliczeniem kosztów finansowych, podatku oraz kosztów amortyzacji (ang. Earnings Before Interest, Taxes, Depreciation and Amortization - EBITDA).

${ }^{76}$ Dyrektywa Rady (UE) 2016/1164 z dnia 12 lipca 2016 r. ustanawiająca przepisy mające na celu przeciwdziałanie praktykom unikania opodatkowania, które mają bezpośredni wpływ na funkcjonowanie rynku wewnętrznego, Dziennik Urzędowy Unii Europejskiej L 193/1.

${ }^{77}$ F. Majdowski, Implementacja klauzuli antyhybrydowej oraz tzw. małej klauzuli antyabuzywnej do ustawy o podatku dochodowym od osób prawnych na skutek „uszczelniania” dyrektywy o spółkach matkach i spółkach córkach, „Przegląd Podatkowy” 2016, nr 2, s. $35-38$.

${ }^{78}$ OECD/G20 Base Erosion and Profit Shifting Project, Limiting Base Erosion Involving Interest Deductionsand Other Financial Payments Action 4: 2015 Final Report, 2015, dalej: Raport BEPS nr 4. 
Miernik EBITDA jest jedną z bardziej rozpowszechnionych ekonomicznych miar rentowności działalności gospodarczej.

Interakcja regulacji CFC z Raportu BEPS nr 3 z regulacjami ograniczającymi potrącalność odsetek z Raportu BEPS nr 4 dotyczy przypadku, gdy osoba kontrolująca dokonuje płatności odsetek z tytułu pożyczki zaciągniętej od spółki CFC, pełniącej funkcję spółki finansowej ${ }^{79}$, i to z perspektywy państwa osoby kontrolującej dochodzi do równoczesnego zastosowania regulacji CFC oraz regulacji nastawionych na zapobieżenie erozji podstawy opodatkowania na skutek płatności odsetek ${ }^{80}$. OECD zachęca by w takich okolicznościach współczynnik EBITDA osoby kontrolującej uwzględniał dochód spółki CFC przypisany na podstawie regulacji CFC, za wyjątkiem tej części dochodu spółki CFC, który składa się z przychodu lub kosztu odsetkowego ponoszonego przez spółkę CFC. Te ostatnie wartości powinny być $\mathrm{z}$ kolei uwzględnione $\mathrm{w}$ wyliczeniu kosztu odsetkowego netto osoby kontrolującej ${ }^{81}$. Autor pragnie zwrócić uwagę, iż takie rozwiązanie może w praktyce zneutralizować ograniczenie potrącalności odsetek płaconych do spółki CFC, pozwalając osobie kontrolującej rozpoznać wyższe koszty uzyskania przychodów z tytułu płatności odsetek do spółki CFC z uwagi na fakt, że koszty odsetek w wyliczeniu kosztu odsetkowego netto „w rękach” osoby kontrolującej będą podlegały pomniejszeniu o odpowiadający przychód odsetkowy spółki CFC. W efekcie, koszt odsetkowy netto w części dotyczącej odsetek uiszczanych przez osobę kontrolującą do spółki CFC będzie równy zero, czyli nie przekroczy progu wyznaczanego przez określoną procentowo wartość EBITDA a odsetki płacone do spółki CFC zawsze będą stanowić z perspektywy osoby kontrolującej koszt podatkowy.

Innym „klasycznym”, aczkolwiek nieporuszonym bezpośrednio przykładem współoddziaływania rekomendacji z Raportu BEPS nr 3 oraz Raportu BEPS nr 4 jest sytuacja gdy spółka finansowa, kwalifikująca się jako spółka CFC, otrzymuje odsetki od powiązanego podmiotu z państwa trzeciego o wysokim poziomie opodatkowania. Jeżeli państwo podmiotu wypłacającego odsetki nie wprowadzi rekomendacji OECD w zakresie ograniczenia prawa do rozpoznania płatności jako kosztu

79 J. Hey, Base Erosion and Profit Shifting and Interest Expenditure, „Bulletin for International Taxation" 2014, nr 6-7, s. 334,

${ }^{80}$ E. Traversa, Interest Deductibility and the BEPS Action Plan: Nihil Novi Sub Sole?, „British Tax Review” 2013, nr 5, s. 610.

${ }^{81}$ Raport BEPS nr 4, pkt 202. 
podatkowego, erozję podstawy opodatkowania tego państwa może w pewnym sensie „sanować” państwo osoby kontrolującej poprzez zakwalifikowanie dochodu odsetkowego jako dochodu CFC. Wówczas, kosztowi podatkowemu w państwie podmiotu wypłacającego towarzyszyć będzie dochód podatkowy w państwie osoby kontrolującej. W lustrzany sposób można argumentować, iż w sytuacji gdy państwo źródła odmówi potrącalności podatkowej, wówczas odpowiednio dochód CFC powinien ulec zmniejszeniu.

Warto odnotować, iż OECD jest przekonane, że rekomendowane dobre praktyki w zakresie ograniczenia potrącalności podatkowej odsetek oraz zbliżonych rodzajowo płatności przyczynią się do zmniejszenia „nacisku” na regulacje CFC poprzez redukcję w grupach międzynarodowych kwoty odsetek netto w związku z obiektywnym zmniejszeniem wysokości finasowania międzygrupowego, co przekładać się będzie na niższy dochód CFC z tytułu odsetek ${ }^{82}$. U podstaw takiego założenia leży oczekiwanie, iż przedsiębiorstwa międzynarodowe ograniczą praktyki przerzucania dochodu poprzez finansowanie międzygrupowe.

\section{Regulacje CFC w świetle punktu 5 Planu Działań}

Raport BEPS nr 5 dotyczący przeciwdziałaniu szkodliwym praktykom podatkowym, z uwzględnieniem zasady transparentności oraz wymogu „substancji”" ${ }^{33}$ nie zawiera bezpośrednio wytycznych w zakresie kształtu regulacji $\mathrm{CFC}^{84}$. Zdaniem autora, kluczową kwestią w zakresie korelacji wytycznych OECD zawartych w Raporcie BEPS nr 3 oraz Raporcie BEPS nr 5 jest udzielenie odpowiedzi na pytanie o obowiązek zaniechania stosowania mechanizmu kompensacyjnego jakim są regulacji CFC w stosunku do podmiotów korzystających z preferencyjnych reżimów podatkowych ${ }^{85}$, które zostaną uznane za dopuszczalne w świetle standardu nakreślonego przez

${ }^{82}$ Raport BEPS nr 4, pkt 204.

${ }^{83}$ OECD/G20 Base Erosion and Profit Shifting, Countering Harmful Tax Practices More Effectively, Taking into Account Transparency and Substance Action 5: 2015 Final Report, 2015, dalej: Raport BEPS nr 5.

${ }^{84}$ H. Liebman, W. Heyvaert, V. Oyen, Countering Harmful Tax Practices: BEPS Action 5 and EU Initiatives - Past Progress, Current Status and Prospects, „European Taxation" 2016, nr 2-3, s. 103.

85 OECD, OECD Tax Policy Study: Corporate Tax Incentives For Foreign Direct Investment, 2001, s. 43. 
OECD w ramach Raportu BEPS nr 5, przede wszystkim na skutek spełnienia kryterium istotnej działalności (ang. substantial activity requirement) ${ }^{86}$. Jak podaje OECD tymi reżimami są, między innymi, reżim własności intelektualnej, reżim spółki holdingowej, reżim centrali/spółki matki, reżim centrum usługowego oraz różnego rodzaju reżimy dla podmiotów z sektora finansowego/leasingowego oraz węziej dla sektora bankowego/ubezpieczeniowego ${ }^{87}$. W świetle regulacji CFC wiele podmiotów działających w ramach ww. reżimów może zostać uznane za spółki CFC, przykładowo z uwagi na nieposiadanie wystarczającej „substancji”" ${ }^{8}$, tj. takie podmioty mogą zostać uznane za sztuczne/niesamodzielne, niespełniające wymogu istotnej działalności, czy też z uwagi na dokonywanie transakcji wyłącznie $\mathrm{z}$ podmiotami powiązanymi ${ }^{89}$. W tym kontekście OECD powołuje się na przykład tzw. spółki „krzak” (ang. letter box/brass plate company) korzystającej z reżimu spółki holdingowej. Reżim spółki holdingowej dopuszczający takie podmioty do korzystania z przywilejów podatkowych zostanie uznany za szkodliwą praktykę podatkową.

Chociaż expressis verbis nie zostało to wyartykułowane w Raporcie BEPS nr 5, to wydaje się, że niewypowiedzianą intencją raportu jest postulat by w sytuacji, gdy dany reżim podatkowy został po spełnieniu określonych warunków uznany za nieszkodliwy, wówczas regulacje CFC państw uczestniczących w pracach OECD przewidywały wyłączenia dla podatników kontrolujących zagraniczne spółki korzystające $\mathrm{z}$ takiego reżimu ${ }^{90}$. Taki wniosek został z kolei zawarty na tle preferencyjnych reżimów podatkowych zidentyfikowanych w ramach Raportu OECD dotyczącego szkodliwych praktyk podatkowych z 1998 r. ${ }^{91}$, po czym po paru latach $\mathrm{w}$ ramach tego samego projektu, ale w ramach raportu cząstkowego, OECD dokonało wolty w przeciwną stronę uznając expressis verbis,

${ }^{86}$ K. Bronżewska, F. Majdowski, Badania i rozwój - jak zwiększyć polską innowacyjność poprzez politykę podatkową?, „Kwartalnik Prawa Podatkowego” 2015, nr 2, s. 88.

${ }^{87}$ Raport BEPS nr 5, pkt 70 i nast.

${ }^{88}$ Raport BEPS nr 5, pkt 87.

${ }^{89}$ LY. Jow, Do the CFC Regimes of the US And Japan Nullify Singapore's Tax Incentives for Headquarters Activities?, „Australian Tax Forum” 2004, nr 19, s. 228.

${ }^{90}$ The BEPS Monitoring Group, Comments on BEPS Action 3: Strengthening the Rules on Controlled Foreign Corporations (Cfcs), 2015, s. 4; P. Arginelli, The Interaction between IP Box Regimes and Compensatory Tax Measures: A Plea for a Coherent and Balanced Approach, [w:] D. Weber (red.), EU Law and the Building of Global Supranational Tax Law: EU BEPS And State Aid, Amsterdam 2017, książka online, s. 15.

${ }^{91}$ OECD, Harmful Tax Competition. An Emerging Global Issue, 1998, pkt 98. 
że nawet gdy dany reżim nie spełnia już przesłanek szkodliwej praktyki podatkowej, to nie powoduje to automatycznie, że państwo członkowskie OECD jest zobligowane do zawieszenia stosowania regulacji CFC względem podatnika korzystającego $\mathrm{z}$ takiego reżimu poprzez kontrolowaną spółkę zagraniczną ${ }^{92}$.

Brak skoordynowania prac OECD w dwóch przytoczonych obszarach przypomina zresztą zbliżone rozważania sprzed kilkunastu laty w ramach Unii Europejskiej, gdzie przed wydaniem orzeczenia w sprawie Cadbury Schweppes ${ }^{93}$ także w sposób generalny postulowano by regulacje CFC państw członkowskich nie znajdowały zastosowania do zagranicznych podmiotów korzystających w innych państwach członkowskich z preferencyjnych reżimów podatkowych zaaprobowanych przez Komisję Europejską oraz zgodnych z wytycznymi Grupy ds. Kodeksu Postępowania ${ }^{94}$, pomimo faktu, iż przedmiotowe wytyczne nie odnosiły się - w przeciwieństwie do Raportu OECD o szkodliwej konkurencji podatkowej z 1998 r. - do regulacji CFC ${ }^{95}$. W tych okolicznościach za co najmniej dwuznaczną należy ocenić postawę niektórych państw, przykładowo Hiszpanii, które zmodyfikowały posiadane przez siebie reżimy patentowe celem odzwierciedlenia wytycznych z Raportu BEPS nr 5 nie zmieniając jednocześnie krajowych regulacji CFC, które w dalszym ciągu nakazują by podmioty korzystające $\mathrm{z}$ podobnych zagranicznych reżimów, nawet tych spełniających w założeniu „wyśrubowane” wymogi istotnej działalności, kwalifikować jako spółki $\mathrm{CFC}^{96}$. Pojawiła się nawet opinia, iż to właśnie osłabienie regulacji CFC w państwach członkowskich przez Trybunał Sprawiedliwości Unii Europejskiej wyrokiem w sprawie Cadbury

92 OECD, The OECD'S Project on Harmful Tax Practices: The 2004 Progress Report, 2004, pkt 18.

93 Wyrok TS z 12.09.2006 r., w sprawie C-196/04, Cadbury Schweppes plc, Cadbury Schweppes Overseas Ltd, przeciwko Commissioners of Inland Revenue, ECLI:EU:C:2006:544.

${ }^{94}$ Fédération des Experts Comptables Européens, FEE Position Paper on Controlled Foreign Company Legislations in the EU, 2002, s. 14; C. Pinto, Tax Competition and EU Law, Kluwer Law International, Hague 2002, s. 233; S. Degrève, R. Molitor, Tax Competition - Current Trends for Company Taxation in Europe, „Tax Notes International” 2006, nr 41, s. 303-304.

${ }^{95}$ S. Steigen, Are Controlled Foreign Company Rules Compatible with the Principle of Freedom of Movement of Capital within the EU?, „EC Tax Journal” 2002, nr 1, s. 22.

${ }^{96}$ F. Serrano Antón, La influencia del Plan de Acción BEPS en la tributación española: impacto en la normativa, incremento de la litigiosidad y el papel de los tribunals, „Estudios financieros. Revista de contabilidad y tributación” 2015, nr 391, s. 104. 
Schweppes przyczyniło się do rozprzestrzenienia się reżimów własności intelektualnej w Unii Europejskiej ${ }^{97}$, co obecnie projekt BEPS częściowo stara się zneutralizować ${ }^{98}$.

\section{Regulacje CFC w świetle punktu 6 Planu DziaŁań}

Raport BEPS nr 6 został poświęcony zapobieganiu przyznawania korzyści płynących $\mathrm{z}$ traktatów podatkowych $\mathrm{w}$ niewłaściwych okolicznościach $^{99}$. W kontekście regulacji CFC, w raporcie tym wskazano, iż podnoszony argument o potencjalnej niezgodności przedmiotowych regulacji $\mathrm{z}$ art. 7 lub art. 10 ust. 5 Modelowej Konwencji (MK) OECD jest niezasadny i że kwestia ta została już uprzednio omówiona w Komentarzu do MK OECD w drodze zapisów pkt 23 Komentarza do art. 1 tej konwencji ${ }^{100}$. Raport BEPS nr 6 sugeruje jednocześnie, że chociaż przepisy MK OECD nie ograniczają zasadniczo prawa do opodatkowania własnych rezydentów podatkowych (a jedynie rezydentów podatkowych innych państw), to wskazanym byłoby dodanie nowego pkt 3 do art. 1 MK OECD celem usunięcia jakichkolwiek wątpliwości w tym zakresie ${ }^{101}$. Taka klauzula wzorowana na amerykańskiej klauzuli zabezpieczającej (ang. saving clause) ${ }^{102}$ stanowiłaby, że - poza określonymi wyjątkami niedotyczącymi regulacji CFC - żadne postanowienia umowy o unikaniu podwójnego opodatkowania nie nakładają ograniczeń na państwo-stronę umowy do nakładania podatków na własnych rezydentów podatkowych ${ }^{103}$. W ocenie autora, rekomendowana

${ }^{97}$ P. Baker, CFC aspects of intellectual property, [w:] W. Nykiel, A. Zalasiński (red.), Tax Aspects of Research and Development within the European Union, Wolters Kluwer, Warszawa 2014, s. 143-144.

${ }^{98}$ R. Bräutigam, Ch. Spengel, F. Streif, Zentrum für Europäische Wirtschaftsforschung (ZEW), Discussion Paper nr 15-055, 2016, s. 21.

${ }^{99}$ OECD/G20 Base Erosion and Profit Shifting, Preventing the Granting of Treaty Benefits in Inappropriate Circumstances, Action 6: 2015 Final Report, 2015, dalej: Raport BEPS nr 6.

${ }^{100}$ Raport BEPS nr 6, pkt 54-55.

${ }^{101}$ J. Schuch, N. Neubauer, The Saving Clause: Article 1(3) of the OECD Model, [w:] M. Lang et al. (red.), Base Erosion and Profit Shifting (BEPS), Schriftenreihe IStR Band 96, Wien 2015, s. 37.

${ }^{102}$ W. Park, Fiscal Jurisdiction and Accrual Basis Taxation: Lifting the Corporate Veil to Tax Foreign Company Profits, „Columbia Law Review” 1978, nr 8, s. 1654; G. Kofler, Some Reflections on the 'Saving Clauses', „Intertax” 2016, nr 8-9, s. 582.

103 G. Graeme, Some Thoughts on the BEPS Proposals to Control Treaty Abuse, [w:] S. Sim, M-J. Soo, Asian Voices: BEPS and beyond, IBFD, Amsterdam 2017, książka 
zmiana będzie miała charakter klaryfikujący (doprecyzowujący) dotychczasowe stanowisko OECD wyrażone w Komentarzu do MK OECD na temat dopuszczalności stosowania regulacji CFC w relacjach traktatowych, gdzie praktyczną różnicą między stanem przed i po dodaniu komentowanej klauzuli będzie możliwość powołania się bezpośrednio na MK OECD (a nie na Komentarz do MK OECD) celem uzasadnienia stosowania regulacji CFC w stosunku do podatników kontrolujących spółki CFC położone w państwach których łączy umowa podatkowa z państwem podatnika.

Za potencjalnie ważną zmianę z perspektywy regulacji CFC wprowadzoną przez Raport BEPS nr 6 można byłoby uznać również doprecyzowanie zapisów art. 23A - art. 23B MK OECD poświęconych metodom eliminacji podwójnego opodatkowania. Ich nowe brzmienie nakazuje zastosować jedną z dwóch metod, czyli metodę zwolnienia (art. 23A MK) lub metodę kredytu podatkowego (art. 23B MK), jedynie względem podatku nałożonego przez drugie państwo jako państwo źródła lub państwo w którym powstał stały zakład podatnika z pierwszego państwa ${ }^{104}$. Innymi słowy, obowiązek eliminacji podwójnego opodatkowania powstaje wyłącznie w przypadku relacji państwo źródła - państwo rezydencji, gdzie państwo rezydencji, tj. rezydencji podatkowej podatnika, jest zobligowane do eliminacji podwójnego opodatkowania powodowanego przez podatek pobrany przez państwo źródła. Gdy natomiast dochodzi do relacji państwo rezydencji - państwo rezydencji, czyli sytuacji gdy dwa państwa roszczą sobie władztwo podatkowe względem tego samego dochodu ale od dwóch różnych podatników będących ich własnymi rezydentami podatkowymi, taki obowiązek nie powstaje. W kontekście regulacji CFC, gdy spojrzy się na to unormowanie właśnie jako relacja państwo rezydencji (państwo rezydencji podatkowej osoby kontrolującej) - państwo rezydencji (państwo rezydencji podatkowej spółki CFC), wówczas można byłoby przyjąć, że państwo osoby kontrolującej nie jest obowiązane do udzielenia kredytu podatkowego na poczet podatku uiszczonego przez spółkę CFC w państwie swojego położenia. Zdaniem autora, taka modyfikacja do wykładni do art. 23A oraz art. 23B MK OECD na potrzeby regulacji CFC nie byłaby jednak poprawna. Kluczowy argument za odrzuceniem możliwości stosowania regulacji CFC w relacjach traktatowych z uwagi na omawiane zmiany osadza się na fakcie, że przedmiotowe zmiany zakładają możliwość opodatkowania przez dwa państwa tego samego dochodu, co

online, s. 11; G. Cooper, Preventing Tax Treaty Abuse, [w:] United Nations Handbook on Selected Issues in Protecting the Tax Base of Developing Countries, New York 2017, s. 360.

${ }^{104}$ Raport BEPS nr 6, pkt. 63-64. 
zresztą potwierdzają przykłady przedłożone przez OECD do tych zmian odnoszące się w przeważającej mierze do konfliktu klasyfikacji podmiotu uzyskującego dany dochód jako transparentny podatkowo. Tymczasem, OECD w pkt 13 Komentarza do art. 7 wyraźnie stwierdza że regulacje CFC polegają na opodatkowaniu przez państwo stosujące te regulacje własnego rezydenta podatkowego od dochodu który nie jest dochodem przedsiębiorstwa drugiego umawiającego się państwa, a który jest wyliczany poprzez odniesienie się do takiego dochodu. Zatem, chociaż nie jest to wprost wyartykułowane, wypada skonkludować, że wyjaśnienia dotyczące zmian do art. 23A oraz art. 23B nie dotyczą opodatkowania na podstawie regulacji CFC.

10. Regulacje CFC w Świetle punktu 8-10 Planu Działań

Raport BEPS nr 8-10 został poświęcony regulacjom cen transferowych $^{105}$. Główna idea przyświecająca pracom OECD w tym obszarze to przywrócenie alokacji podlegającego opodatkowaniu dochodu do podmiotu, którego działania doprowadziły do jego powstania (ang. align transfer pricing outcome with value creation $)^{106}$ poprzez eliminację, między innymi, praktyk umownego ale nieodzwierciedlającego rzeczywistości przypisywania funkcji czy też kapitału w ramach grupy podmiotów powiązanych ${ }^{107}$.

W kontekście regulacji CFC Raport BEPS nr 8-10 przyjmuje, że ich pomocnicze zastosowanie w stosunku do regulacji cen transferowych może znaleźć zastosowanie w stosunku do tzw. nadmiernie dokapitalizowanych ale niewykonujących istotnych czynności spółek finansowych (ang. cash-boxes) udzielających pożyczek innym podmiotom $z$ grupy bez realnego ponoszenia ryzyka związanego z taką działalnością, przykładowo niewypłacalności dłużnika ${ }^{108}$. Chociaż niektórzy komentatorzy kwestionują zasadność posługiwania się wyżej przedstawioną koncepcją spółki finansowej jako założenia odbiegającego od realiów gospodarczych ${ }^{109}$, tak OECD

${ }^{105}$ OECD/G20 Base Erosion and Profit Shifting, Aligning Transfer Pricing Outcomes with Value Vreation ACTIONS 8-10: 2015 Final Reports, 2015, dalej: Raport BEPS nr 8-10.

${ }^{106}$ W. Schön, Transfer Pricing Issues of BEPS in The Light Of EU Law, „British Tax Review" 2015, nr 3, s. 2.

${ }^{107}$ M. Gaffney, BEPS - Basically, Everyone on a Profit Split, „Tax Notes International” 2015, nr 147, s. 544.

${ }^{108}$ Raport BEPS nr 8-10, s. 11.

${ }^{109}$ N. Boidman, M. Kandev, The OECD's Cash-box Notion is Fundamentally Flawed, Writers Say, „Tax Notes International” 2016, nr 83, s. 619; J. Wittendorf, The Poison Pill of 
uznaje, iż tego typu podmiot nie powinien być uprawniony w świetle cen transferowych do nadmiernego zysku, rozumianego jako zysk ponad zysk który zostałby uzyskany z tytułu udzielania pożyczki bez ryzyka ${ }^{110}$. Erozja podstawy opodatkowania $\mathrm{z}$ tytułu płatności wynagrodzenia odsetkowego do takiego podmiotu powinna być ograniczona przez rekomendacje $\mathrm{z}$ Raportu BEPS nr 4 dotyczące podatkowej potrącalności odsetek, a ponadto taka spółka powinna zostać zaklasyfikowana jako spółka CFC na podstawie rekomendacji z Raportu BEPS nr 3 jeżeli prowadzi ograniczoną lub żadną działalność gospodarczą ${ }^{111}$. W rezultacie, dochód spółki CFC zmniejszony do poziomu zysku bez ryzyka mógłby stanowić podstawę do opodatkowania osoby kontrolującej.

Poza powyższym przykładem Raport BEPS nr 8-10 nie zawiera wprost innych rozważań na temat regulacji CFC. W innym opracowaniu autor starał się wykazać, iż zasada rynkowości istotnie wzmocniona w narzędzia badania „treści” transakcji poprzez uprawnienia do „przełamywania” umownego przypisania funkcji oraz ryzyka nie jest w stanie zastąpić roli pełnionej przez regulacje CFC ${ }^{112}$. Taka paralelność ma co najwyżej charakter częściowy.

\section{WNIOSKI KOŃCOWE}

Chociaż według deklaracji OECD projekt BEPS miał mieć charakter holistyczny ${ }^{113}$, niemniej trudno jest wskazać na koordynację pomiędzy rekomendacjami z poszczególnych punktów z Planu Działań OECD z 2013 r. ${ }^{114} \mathrm{~W}$ szczególności, analiza Raportów BEPS nr 2 oraz nr 4 pozwala jednak postawić tezę, iż regulacje CFC odpowiednio w stosunku do regulacji antyhybrydowych oraz regulacji dotyczących potrącalności podatkowej

BEPS: M↔A and Intercompany Financing Transactions, „Tax Notes International” 2016, nr 83, s. 517.

${ }^{110}$ M. de Lange, P. Lankhorst, R. Hafkenscheid, (Non-)recognition of Transactions between Associated Enterprises: on Behaving in a Commercially Rational Manner, DecisionMaking Traps and BEPS, „International Transfer Pricing Journal” 2015, nr 3-4, s. 90.

${ }^{111}$ Raport BEPS nr 8-10, s. 11.

${ }^{112}$ F. Majdowski, K. Bronżewska, Revolutionary Changes to the Arm's Length principle..., s. 210-224.

${ }^{113}$ OECD/G20, Addressing Base Erosion and Profit Shifting, 2013, s. 7.

114 The BEPS Monitoring Group, Overall evaluation of the G20/OECD Base Erosion and Profit Shifting (BEPS) project, 2015, s. 3. 
odsetek i innych płatności finansowych mają charakter środka uzupełniającego, alternatywnego względem podstawowych rekomendacji zawartych w tych raportach ${ }^{115}$. Na tym tle spotkać można również pogląd, że rekomendacje zawarte w Raporcie BEPS nr 2 oraz 4 są zbyt skomplikowane i wielowarstwowe, w efekcie czego ich zaimplementowanie może wiązać się z bardzo dużym wysiłkiem ze strony państw rozwijających się, bądź nawet okazać się niemożliwe. Rozwiązaniem zdecydowanie prostszym w tym wymiarze byłoby zaimplementowanie rozbudowanych regulacji CFC przez państwa rozwinięte, które w skrajnej formie całkowicie eliminowałyby odroczenie opodatkowania (ang. full-inclusion CFC rules), ale również ukrócałyby praktyki związane $\mathrm{z}$ hybrydyzacją/płatnościami finansowymi ${ }^{116}$. Analogiczna treściowo jest również supozycja, by w kontekście rekomendacji dotyczących cen transferowych z Raportu BEPS nr 8-10 regulacje CFC odgrywały istotną rolę uzupełniającą $z$ uwagi na fakt, że implementacja rekomendacji w zakresie cen transferowych może okazać się utrudniona ${ }^{117}$. W przypadku wyzwań związanych $\mathrm{z}$ gospodarką cyfrową o których mowa w Raporcie BEPS nr 1 oraz preferencyjnymi reżimami podatkowymi o których mowa w Raporcie BEPS nr 5 regulacje CFC mają charakter kompensacyjny, neutralizując w sposób samodzielny korzyści podatkowe uzyskiwane odpowiednio na skutek cyfryzacji oraz szkodliwych praktyk podatkowym części państw.

Autor pragnie na końcu postawić tezę, że spójnym byłoby zhierarchizowanie poszczególnych punktów działania OECD, tak by w ramach transgranicznego zwalczania BEPS pierwszeństwo w zastosowaniu miały regulacje cen transferowych, następnie regulacje przeciwdziałające hybrydyzacji oraz potrącalności płatności finansowych, by na końcu stosować ewentualnie regulacje CFC. Taki multilateralizm podatkowy wymagałby jednak konsensu politycznego, o co jak wskazuje prof. Jeffrey Owens, wieloletni dyrektor Centrum Polityki Podatkowej oraz Administracji OECD, z uwagi na rozbieżne interesy gospodarcze pomiędzy państwami jest wyjątkowo trudno ${ }^{118}$.

${ }^{115}$ A. Dourado, May You Live in Interesting Times, „Intertax” 2016, nr 1, s. 4-5.

116 The BEPS Monitoring Group, Overall..., s. 8

117 F. Majdowski, K. Bronżewska, Revolutionary Changes to the Arm's Length Principle..., s. 224

${ }^{118} \mathrm{Na}$ podstawie rozmowy autora przeprowadzonej z prof. Jeffreyem Owens podczas konferencji „Addressing tax challenges in a global digital environment” w Xiamen (Chiny) w dniu 22 lipca $2018 \mathrm{r}$. 


\section{BIBLIOGRAFIA}

Arginelli P., The Interaction between IP Box Regimes and Compensatory Tax Measures: a Plea for a Coherent and Balanced Approach, [w:] D. Weber (red.), EU Law and the Building of Global Supranational Tax Law: EU BEPS and State Aid, Amsterdam 2017.

Athanasiou A., BEPS Action 3 (CFC rules): Final CFC Report Leaves Options Open, „Tax Notes International" 2015, $\mathrm{nr} 180$.

Athanasiou A., Lack of Consensus on CFC Rules Likely Here to Stay, „Tax Notes International" 2015, $\mathrm{nr} 78$.

Athanasiou A., OECD's CFC Rule Draft Likely to Spur Controversy, „Tax Notes International” 2015, $\mathrm{nr} 78$.

Ault H., Arnold B., Protecting the Tax Base of Developing Countries: an Overview, Papers on Selected Topics in Protecting the Tax Base of Developing Countries, 2013, $\mathrm{nr} 1$.

Ault H., Schön W., Shay S., Base Erosion and Profit Shifting: a Roadmap for Reform, „Bulletin for International Taxation” 2014, nr 6-7.

Avi-Yonah R., Full Circle? The Single Tax Principle, BEPS and the New US Model, „Public Law and Legal Theory Research Paper Series" 2015, nr 480.

Baker P., BEPS Appraisal: Interview with Philip Baker QC, „Journal of International Taxation" 2015, nr 1.

Baker P., CFC Aspects of Intellectual Property, [w:] W. Nykiel, A. Zalasiński (red.), Tax Aspects of Research and Development within the European Union, Warszawa 2014.

Boidman N., Kandev M., The OECD's Cash-box Notion is Fundamentally Flawed, Writers Say, „Tax Notes International” 2016, nr 83.

Brauner Y., BEPS: an Interim Evaluation, „World Tax Journal” 2014, nr 1.

Bräutigam R., Spengel Ch., Streif F., Decline of CFC Rules and Rise of IP Regimes: How the ECJ Affects Tax Competition and Economic Distortions in Europe, Zentrum für Europäische Wirtschaftsforschung (ZEW), Discussion Paper nr 15-055, 2016.

Bronżewska K., Majdowski F., Badania i rozwój - jak zwiększyć polską innowacyjność poprzez politykę podatkowa?, „Kwartalnik Prawa Podatkowego” 2015, nr 2.

Cooper G., Preventing Tax Treaty Abuse, [w:] United Nations Handbook on Selected Issues in Protecting the Tax Base of Developing Countries, New York 2017.

Degrève S., Molitor R., Tax Competition - Current Trends for Company Taxation in Europe, „Tax Notes International” 2006, $\mathrm{nr} 41$.

De Lange M., Lankhorst P., Hafkenscheid R., (Non-)recognition of Transactions between Associated Enterprises: On Behaving in a Commercially Rational Manner, Decision-Making Traps and BEPS, „International Transfer Pricing Journal” 2015, nr 3-4.

Doernberg R., Hinnekens L., Electronic Commerce and International Taxation, Hague 1999.

Dourado A., Aggressive Tax Planning in EU Law and in the Light of BEPS: The EC Recommendation on Aggressive Tax Planning and BEPS Actions 2 and 6, „Intertax” 2015, nr 1 .

Dourado A., May You Live in Interesting Times, „Intertax” 2016, nr 1.

Dourado A., The Meaning of Aggresive Tax Planning and Avoidance in the European Union and the OECD: An Example of Legal Pluralism in International Tax Law, [w:] J. English (red.), International Tax Law: New Challenges to and from Constitutional and Legal Pluralism, Amsterdam 2016. 
Dourado A., The Role of CFC Rules in the BEPS Initiative and in the EU, „British Tax Review" 2015, nr 3.

Durst M., Self-help and Altruism: Exploring the Problem of Tax Base Erosion in Developing Countries, Bloomberg BNA, „Tax Management Transfer Pricing Report” 2014.

English J., BEPS Action 1: Digital Economy - EU Law Implications, „British Tax Review”, 2015, nr 3.

Gaffney M., BEPS - Basically, Everyone on a Profit Split, „Tax Notes International” 2015, nr 147.

Glicklich P., Leitner A., U.S. Taxation of E-commerce under Subpart F-Missing Pieces Leave Uncertainty, „Bulletin for International Taxation” 2001, nr 9-10.

Graeme G., Some Thoughts on the BEPS Proposals to Control Treaty Abuse, [w:] S. Sim, M-J. Soo, Asian Voices: BEPS and beyond, Amsterdam 2017.

Harris P., Neutralizing Effects of Hybrid Mismatch Arrangements, [w:] A. Trepelkov, H. Tonino, D. Halka (red.), United Nations Handbook on Selected Issues in Protecting the Tax Base of Developing Countries, New York 2017.

Haslehner W., The Controlled Foreign Company Regime, [w:] D. Weber, J. van de Streek (red.), The EU Common Consolidated Corporate Tax Base: Critical Analysis, Alphen aan den Rijn 2017.

Helminem M., EU Law Compatibility of BEPS Action 2: Neutralising the Effects of Hybrid Mismatch Arrangements, „British Tax Review” 2015, nr 3.

Hey J., Base Erosion and Profit Shifting and Interest Expenditure, „Bulletin for International Taxation" 2014, nr 6-7.

Holmes K., Regulacje zapobiegające unikaniu opodatkowania, tłum. A. Biegalski, [w:] H. Hamaekers, K. Holmes, J. Głuchowski, T. Kardach, W. Nykiel, Wprowadzenie do międzynarodowego prawa podatkowego, Warszawa 2006.

Jow LY., Do the CFC Regimes of the US and Japan Nullify Singapore's Tax Incentives for Headquarters Activities?, „Australian Tax Forum” 2004, nr 19.

Kahlenberg Ch., The Interplay between the OECD Recommendations of Actions 2 And 3 Regarding Hybrid Structures, „Intertax” 2016, nr 4.

Kane M., The Role of Controlled Foreign Company Legislation in the OECD Base Erosion and Profit Shifting Project, „Bulletin for International Taxation” 2014, nr 6-7.

Kofler G., Some Reflections on the 'Saving clauses', „Intertax” 2016, nr 8-9.

Kuntz J., Peroni R., US International Taxation, Part B Taxation of U.S. Persons with Foreign Activities, B3.04. Subpart F Income (Section 952), WG\&L International Treatises, Thomson Reuters, 2015.

Liebman H., Heyvaert W., Oyen V., Countering Harmful Tax Practices: BEPS Action 5 and EU Initiatives - Past Progress, Current Status And Prospects, „European Taxation” 2016, nr 2-3.

Lüdicke J., „Tax Arbitrage” with Hybrid Entities: Challenges And Responses, „Bulletin for International Taxation" 2014, nr 6-7.

Maisto G., Controlled Foreign Company Legislation, Corporate Residence and Anti-Hybrid Arrangement Rules, „Bulletin for International Taxation” 2014, nr 6-7.

Majdowski F., Implementacja klauzuli antyhybrydowej oraz tzw. małej klauzuli antyabuzywnej do ustawy o podatku dochodowym od osób prawnych na skutek „uszczelniania” dyrektywy o spółkach matkach i spółkach córkach, „Przegląd Podatkowy” 2016, nr 2. 
Majdowski F., Polskie regulacje dotyczące zagranicznej spółki kontrolowanej na tle rekomendacji OECD oraz wymogów unijnych (cz. 1), „Biuletyn Instytutu Studiów Podatkowych" 2016, nr 9.

Majdowski F., Zróżnicowane kryteria zwalczania zjawiska unikania opodatkowania w podatku dochodowym od osób prawnych, „Zeszyty Naukowe Sądownictwa Administracyjnego" 2016, nr 4.

Majdowski F., Bronżewska F., Revolutionary Changes to the Arm's Length Principle under The OECD BEPS Project: Have CFC Rules Become Redundant?, „Intertax” 2018, nr 3.

Maquire N., Anolik S., Subpart F and Source of Income Issues in E-commerce, „Tax Notes” 2000, nr 89.

Oguttu A., OECD's Action Plan on tax Base Erosion and Profit Shifting: Part 2 - a Critique of Some Priority OECD Actions from an African Perspective - Addressing Excessive Interest Deductions, Treaty Abuse and The Avoidance of The Status Of a Permanent Establishment, „Bulletin for International Taxation” 2016, nr 6.

Owens J., The Taxation of Multinational Enterprises: An Elusive Balance, „Bulletin for International Taxation" 2013, nr 8.

Panayi Ch., Advanced Issues in International and European Tax Law, Oxford 2015.

Panayi Ch., International Tax Law Following the OECD/G20 Base Erosion and Profit Shifting project, „Bulletin for International Taxation” 2016, nr 11.

Park W., Fiscal Jurisdiction and Accrual Basis Taxation: Lifting the Corporate Veil to Tax Foreign Company Profits, „Columbia Law Review” 1978, nr 8.

Piantavigna P., Tax Abuse and Aggressive Tax Planning in the BEPS Era: How EU Law and The OECD Are Establishing a Unifying Conceptual Framework in International Tax Law, Despite Linguistic Discrepancies, „World Tax Journal” 2017, nr 1.

Picciotto S., Can the OECD Mend the International Tax System?, „Tax Notes International” 2013, nr 71.

Pinto C., Tax Competition and EU Law, Hague 2002.

Pinto D., A Proposal to Reform Income Anti-tax-deferral Regimes, „Australian Journal of Taxation" 2009, nr 12.

Pinto D., Exclusive Source or Residence-Based Taxation - Is a New and Simpler World Tax Order Possible?, „Bulletin for International Taxation” 2007, nr 7.

Pistone P., Szudoczky R., The Coordination of Tax Policies in the EU, [w:] M. Lang, P. Pistone, J. Schuch, C. Staringer (red.), Introduction to European Tax Law on Direct Taxation, Wien 2016.

Popa O., Past, Present and Future of Tax Structuring Using Hybrid Entity Mismatches, [w:] M. Cotrut (red.), International Tax Structures in the BEPS Era: an Analysis of Anti-abuse Measures, Amsterdam 2015.

Rosenbloom H., Brothers J., Reflections on the Intersection of U.S. Tax Treaty Policy, U.S. Tax Reform, And BEPS, „Tax Notes International” 2015, nr 78.

Schler M., BEPS Action 2: Ending Mismatches on Hybrid Instruments, Part 2, „Tax Notes International" 2014, nr 75.

Schön W., Transfer Pricing Issues of BEPS in the Light of EU Law, „British Tax Review” 2015, nr 3. 
Schuch J., Neubauer N., The Saving Clause: Article 1(3) of the OECD Model, [w:] M. Lang et al. (red.), Base Erosion and Profit Shifting (BEPS), Schriftenreihe IStR Band 96, Wien 2015.

Serrano Antón F., La influencia del Plan de Acción BEPS en la tributación española: impacto en la normativa, incremento de la litigiosidad y el papel de los tribunals, „Estudios financieros. Revista de contabilidad y tributación” 2015, nr 391.

Shaviro D., The Two Faces of the Single Tax Principle, „Brooklyn Journal of International Law" 2016, nr 3.

Shay S., Fleming J., Peroni R., Designing a 21st Century Corporate Tax - An Advance US Minimum Tax on Foreign Income and Other Measures to Protect the Base, „Florida Tax Review” 2015, nr 9.

Steigen S., Are Controlled Foreign Company Rules Compatible with the Principle of Freedom of Movement of Capital within the EU?, „EC Tax Journal” 2002, nr 1.

Traversa E., Interest Deductibility and the BEPS Action Plan: Nihil Novi Sub Sole?, „British Tax Review” 2013, nr 5.

Vanistendael F., EU vs BEPS: Conflicting Concepts of Tax Avoidance, [w:] D. Weber (red.), EU Law and the Building of Global Supranational Tax Law: EU BEPS and State Aid, Amsterdam 2017.

Vanistendael F., Is Tax Avoidance the Same Thing under the OECD Base Erosion and Profit Shifting Action Plan, National Tax Law and EU Law?, „Bulletin for International Taxation" 2016, nr 3.

Vann R., International Aspects of Income Tax, [w:] V. Thuronyi (red.), Tax Law Design and Drafting, Hague 1998.

Van Weeghel S., Emmerink F., Global Developments and Trends in International Antiavoidance, „Bulletin for International Taxation” 2013, nr 8.

Wittendorf J., The Poison Pill of BEPS: MઐA and Intercompany Financing Transactions, „Tax Notes International” 2016, nr 83.

Yoder L., Subpart F in Turmoil: Low-taxed Active Income under Siege, „Taxes - The Tax Magazine" 1999, nr 3.

The BEPS Monitoring Group, Comments on BEPS Action 3: Strengthening the Rules on Controlled Foreign Corporations (CFCs), 2015.

The BEPS Monitoring Group, Overall evaluation of the G20/OECD Base Erosion and Profit Shifting (BEPS) project, 2015.

Fédération des Experts Comptables Européens, FEE Position Paper on Controlled Foreign Company Legislations in the EU, 2002.

G20, Communiqué from G20 Leaders Meeting (Los Cabos, Mexico), 2012.

G20, Final Communiqué Meeting of Finance Ministers and Central Bank Governors, 2012.

Internal Revenue Service, Guidance under Subpart F Relating to Partnerships and Branches (projekt Rozporządzenia nr TD 8767), 1998.

Internal Revenue Service, Treatment of Hybrid Arrangements under Subpart F (okólnik nr Notice 98-11), 1998. 
Internal Revenue Service, Treatment of Hybrid Arrangements under Subpart F (okólnik nr Notice 98-35), 1998.

Internal Revenue Service, Withdrawal of Guidance under Subpart F relating to Partnerships and Branches; and Issuance of New Guidance under Subpart F Relating to Certain Hybrid Transactions (projekt Rozporządzenia nr REG-113909-98), 1999.

OECD, Action Plan on Base Erosion and Profit Shifting, 2013.

OECD, Addressing Base Erosion and Profit Shifting, 2013.

OECD/G20 Base Erosion and Profit Shifting Project, Addressing the Tax Challenges of the Digital Economy, Action 1: 2015 Final Report, 2015.

OECD/G20 Base Erosion and Profit Shifting Project, Neutralising the Effects of Hybrid Mismatch Arrangements Action 2: 2015 Final Report, 2015.

OECD/G20 Base Erosion and Profit Shifting Project, Designing Effective Controlled Foreign Company Rules Action 3: 2015 Final Report, 2015.

OECD/G20 Base Erosion and Profit Shifting Project, Limiting Base Erosion Involving Interest Deductions and Other Financial Payments Action 4: 2015 Final Report, 2015.

OECD/G20 Base Erosion and Profit Shifting, Countering Harmful Tax Practices More Effectively, Taking into Account Transparency and Substance Action 5: 2015 Final Report, 2015.

OECD/G20 Base Erosion and Profit Shifting, Preventing the Granting of Treaty Benefits in Inappropriate Circumstances, Action 6: 2015 Final Report, 2015.

OECD/G20 Base Erosion and Profit Shifting, Aligning Transfer Pricing Outcomes with Value Creation Actions 8-10: 2015 Final Reports, 2015.

OECD/G-20, Tax Annex to the St. Petersburg G20 Leaders' Declaration, 2013.

OECD, Harmful Tax Competition. An Emerging Global Issue, 1998.

OECD, OECD Tax Policy Study: Corporate Tax Incentives for Foreign Direct Investment, 2001.

OECD, The OECD'S Project on Harmful Tax Practices: The 2004 Progress Report, 2004.

Treasury Department Office of Tax Policy, The deferral of income earned through US controlled foreign corporations: a policy study, 2000.

U.S. Department of the Treasury, General Explanations of the Administration's Fiscal Year 2010 Revenue Proposals, 2009.

U.S. Joint Committee on Taxation, Present Law and Backgrounds Related to Possible Income Shifting and Transfer Pricing. Scheduled of a Public Hearing before the House Committee on Ways and Means, 2010.

\begin{abstract}
The subject of the article is to present the OECD's recommendations issued within the Base Erosion and Profit Shifting (BEPS) project as regards the relation between CFC regulations and the other action points from this project. The analysis reveals that such recommendations do not have a holistic nature, i.e. they do not envisage an explicit hierarchy between them, and that the impact of CFC regulations on the BEPS phenomenon has in majority of cases a subsidiary character in light of the primary recommendations, such as, for instance, the ones on neutralizing tax hybridization, limiting tax deductibility of financial payments or fighting harmful tax regimes.
\end{abstract}

Keywords: BEPS, CFC regulations, digital economy, hybrid entities and payments, harmful tax regimes, transfer pricing 